OPEN ACCESS

Edited by:

Simon Gilroy,

University of Wisconsin-Madison,

United States

Reviewed by:

Nobuhiro Suzuki,

Sophia University, Japan

Won-Gyu Choi,

University of Nevada, Reno,

United States

*Correspondence:

Bożena Szal

szal@biol.uw.edu.pl

Anna Podgórska

apodgorski@biol.uw.edu.pl

Specialty section:

This article was submitted to

Plant Cell Biology,

a section of the journal

Frontiers in Plant Science

Received: 16 March 2017

Accepted: 20 July 2017

Published: 22 August 2017

Citation:

Podgórska A, Burian M and Szal B (2017) Extra-Cellular But Extra-Ordinarily Important for Cells: Apoplastic Reactive Oxygen Species Metabolism. Front. Plant Sci. 8:1353.

doi: $10.3389 /$ fpls.2017.01353

\section{Extra-Cellular But Extra-Ordinarily Important for Cells: Apoplastic Reactive Oxygen Species Metabolism}

\author{
Anna Podgórska*, Maria Burian and Bożena Szal* \\ Institute of Experimental Plant Biology and Biotechnology, Faculty of Biology, University of Warsaw, Warsaw, Poland
}

Reactive oxygen species (ROS), by their very nature, are highly reactive, and it is no surprise that they can cause damage to organic molecules. In cells, ROS are produced as byproducts of many metabolic reactions, but plants are prepared for this ROS output. Even though extracellular ROS generation constitutes only a minor part of a cell's total ROS level, this fraction is of extraordinary importance. In an active apoplastic ROS burst, it is mainly the respiratory burst oxidases and peroxidases that are engaged, and defects of these enzymes can affect plant development and stress responses. It must be highlighted that there are also other less well-known enzymatic or nonenzymatic ROS sources. There is a need for ROS detoxification in the apoplast, and almost all cellular antioxidants are present in this space, but the activity of antioxidant enzymes and the concentration of low-mass antioxidants is very low. The low antioxidant efficiency in the apoplast allows ROS to accumulate easily, which is a condition for ROS signaling. Therefore, the apoplastic ROS/antioxidant homeostasis is actively engaged in the reception and reaction to many biotic and abiotic stresses.

Keywords: antioxidants, apoplastic reactive oxygen species, biotic and abiotic stress, detoxification, respiratory burst enzymes

\section{INTRODUCTION}

The term reactive oxygen species (ROS) usually encompasses singlet oxygen $\left({ }^{1} \mathrm{O}_{2}\right)$, superoxide ion $\left(\mathrm{O}_{2}^{\bullet-}\right)$, hydrogen peroxide $\left(\mathrm{H}_{2} \mathrm{O}_{2}\right)$, and hydroxyl radical $(\mathrm{OH} \cdot)$; however, other molecules, such as organic hydroperoxides (ROOH), are also included in this group (Simon et al., 2000). ROS can be generated in all cellular compartments through non-enzymatic mechanisms, such as electron flow in electron transport chains (ETC), or as byproducts of enzymatic reactions (Desikan et al., 2005). ROS are reactive and cause damage to macromolecules (proteins, lipids, and nucleic acids) affecting cellular functioning, but more recent evidence indicates that ROS play important roles in signaling and cell adaptation to stress. Mechanisms of intracellular ROS production and ROS detoxification have been extensively reviewed (Halliwell, 2006; Das and Roychoudhury, 2014); however, apoplastic ROS (apROS) metabolism has received less attention.

Only a small quantity of ROS is localized within the apoplast, apROS have an important role in plant development and plant responses to various stress conditions. We elucidate how apROS are engaged in signal transduction from extracellular spaces to the cell interior and may directly eliminate invading pathogens. Moreover, apROS metabolism regulates the plant cell division rate and cell elongation, and consequently whole plant growth (Barceló and Laura, 2009). It was shown 
that one of the components regulating cell proliferation is apoplast-localized low-mass antioxidants (Kato and Esaka, 1999; Potters et al., 2000). Growth by elongation is limited by the extension of cell walls in what is the result of two processes in which ROS are engaged: loosening of load-bearing bonds in the wall matrix and stiffening through the insertion of stabilizing cross-links between load-bearing polymers (Chen and Schopfer, 1999; Pedreira et al., 2004; Kärkönen and Kuchitsu, 2015). The presence of ROS in apoplastic spaces has mainly been demonstrated using microscopic methods (e.g., deposits of cerium peroxides observed in TEM or probes that became fluorescent when oxidized by ROS), but precise concentrations of apROS were also estimated in some plant species. The concentration of $\mathrm{H}_{2} \mathrm{O}_{2}$ in apoplastic fluid was about 10-25 pmol. $\mathrm{g}^{-1} \mathrm{FW}$ under control conditions and increased several fold under stress conditions (Hernández et al., 2001; DiazVivancos et al., 2006). The question remains how the apoplastic respiratory burst does not become toxic for plants. Our aim in this update is to provide a concise overview of current knowledge about long known ROS producing mechanisms and also propose less prominent apoplastic ROS sources. Furthermore we discuss data regarding antioxidant capacity in the apoplast.

\section{APOPLASTIC ROS FORMATION}

\section{NADPH Oxidases}

Plant NADPH oxidases, termed respiratory burst oxidase homologs (RBOHs), are located in the plasma membrane and generate apoplastic $\mathrm{O}_{2}^{\bullet-}$ using cytosolic NADPH as an electron donor (Figure 1). Plant NADPH oxidases are composed of six transmembrane domains and cytosolic FAD- and NADPHbinding domains (Kadota et al., 2015). The cytoplasmic $\mathrm{N}$-terminal region of plant NADPH oxidases contains two highly conserved EF-hand motifs that are responsible for regulating $\mathrm{RBOH}$ activity; however, conformational changes mediated by $\mathrm{Ca}^{2+}$ binding occur in only one EF-hand (Oda et al., 2010). Calcium-dependent activation of $\mathrm{RBOH}$ activity is also regulated by protein phosphorylation (Kimura et al., 2012), RBOH-lipids (Zhang Y. et al., 2009), and RBOH-specific protein interactions (Kawarazaki et al., 2013; Kaur et al., 2014). The activity of plant $\mathrm{RBOHs}$ has to be tightly regulated to diverse stimuli. However, in opposite to animal systems, only a few proteins that interact to the N-terminal extension of plant RBOHs and mediate positive or negative regulation of its activity has been found (Sumimoto, 2008). Recently, a low temperature-inducible protein AtSRC2 was found to activate AtRBOHD (Kawarazaki et al., 2013). It is known that conformational changes of phosphorylated RBOHs protein expose them to interaction with Rac GTPases (Wong et al., 2007). Rac GTPases participates in a wide variety of signaling events in plants (Nagawa et al., 2010). Several Rac homologs have been shown to activate plant RBOHs (Kawasaki et al., 1999; Wong et al., 2007). On the other hand Rac5 protein in N.icotiana tabacum down-regulated NtRbohD (Morel et al., 2004). Among other type of protein interactions the binding of calcineurin $\mathrm{B}$-like protein $(\mathrm{CBL})$-interacting protein kinase 26 (CIPK26) to AtRBOHF was shown. CIPK26-RBOH association negatively modulated activity of RBOH (Kimura et al., 2013). A role for extracellular ATP in $\mathrm{RBOH}$ activity regulation was also suggested (Song et al., 2006). RBOHs belong to a multigene family: $10 \mathrm{RBOH}$ s were identified in Arabidopsis, 9 in Oryza sativa, and 2 in N. benthamiana (Marino et al., 2012; Kaur et al., 2014). Individual $R B O H$ s differ in their expression pattern across plant tissues and organs, suggesting that their function is diversified. AtRBOH expression was roughly divided by Sagi and Fluhr (2006) into three categories according to the places of their occurrence: expression in whole plant (AtRBOHD and $F$ ), in roots (AtRBOH $A-G, I$ ), and in pollen (AtRBOHH and $J$ ), but in other studies it was shown that, e.g., AtRBOHB is expressed in germinating seeds (Müller et al., 2009).

\section{Peroxidases}

Peroxidases (POXs) can be differentiated into class I POXs, which are intracellular, and class III POXs (E.C. 1.11.1.7) which are secreted to the vacuole or exported to the extracellular space. POXs are heme-containing enzymes involved in ROS production (in hydroxylic and oxidative cycles) and elimination (peroxidative cycle, discussed later) (Figure 1). The activity of POX in an oxidative cycle (using NADH as a substrate) or peroxidative cycle (using phenolics as a substrate) was measured in EWF (extracellular washing fluids) from different zones of maize root and leaf (Maksimović et al., 2008). In the oxidative cycle POXs reduce $\mathrm{O}_{2}$ to $\mathrm{O}_{2}^{\bullet-}$ or $\mathrm{H}_{2} \mathrm{O}_{2}$ using apoplastic reductants, and in the hydroxylic cycle POXs catalyze the reaction in which $\mathrm{OH}$. is produced from $\mathrm{H}_{2} \mathrm{O}_{2}$ and $\mathrm{O}_{2}^{\bullet-}$ (Chen and Schopfer, 1999). In the Arabidopsis genome 73 POX isoforms were identified (Tognolli et al., 2002) - among these only 6 were predicted not to be secreted to the apoplast (Valério et al., 2004). Using multidimensional protein identification technology, it was possible to identify proteins tightly bound to the cell wall, and several POXs in the cell wall proteome (POX1, 2, 12, 30, 31, $57,64)$ were revealed (Bayer et al., 2006). In a novel approach, plasmalemma-bound POX isoforms were identified that seemed to have N-terminal transmembrane domains (Mika et al., 2008). POX genes are mainly expressed in roots, but they have also been detected in other plant organs (Tognolli et al., 2002). A crucial element in the production of ROS by POXs appears to be a transient alkalinization of the apoplast (Bolwell et al., 1995). The regulation of 7 POX genes by KUA1 [a transcription factor (TF) upregulated during expansion growth of leaves] alludes to the particular role of these enzymes in developing processes (Schmidt et al., 2016 and references therein). It was also shown that in Arabidopsis POXs are responsible for about 50\% of the $\mathrm{H}_{2} \mathrm{O}_{2}$ produced during the oxidative burst in pathogen defense (O’Brien et al., 2012a). Additionally, apROS generated by POXs can activate the transcription of RBOHs, which allows further accumulation of apROS in response to stress (O'Brien et al., 2012a).

\section{Oxalate Oxidases}

Oxalate oxidases (OXOs; EC 1.2.3.4) belong to the germinlike protein (GLP) family. GLPs have been reported to possess different enzyme activities, such as superoxide dismutase and polyphenol oxidase, and some of them possess OXO activity 


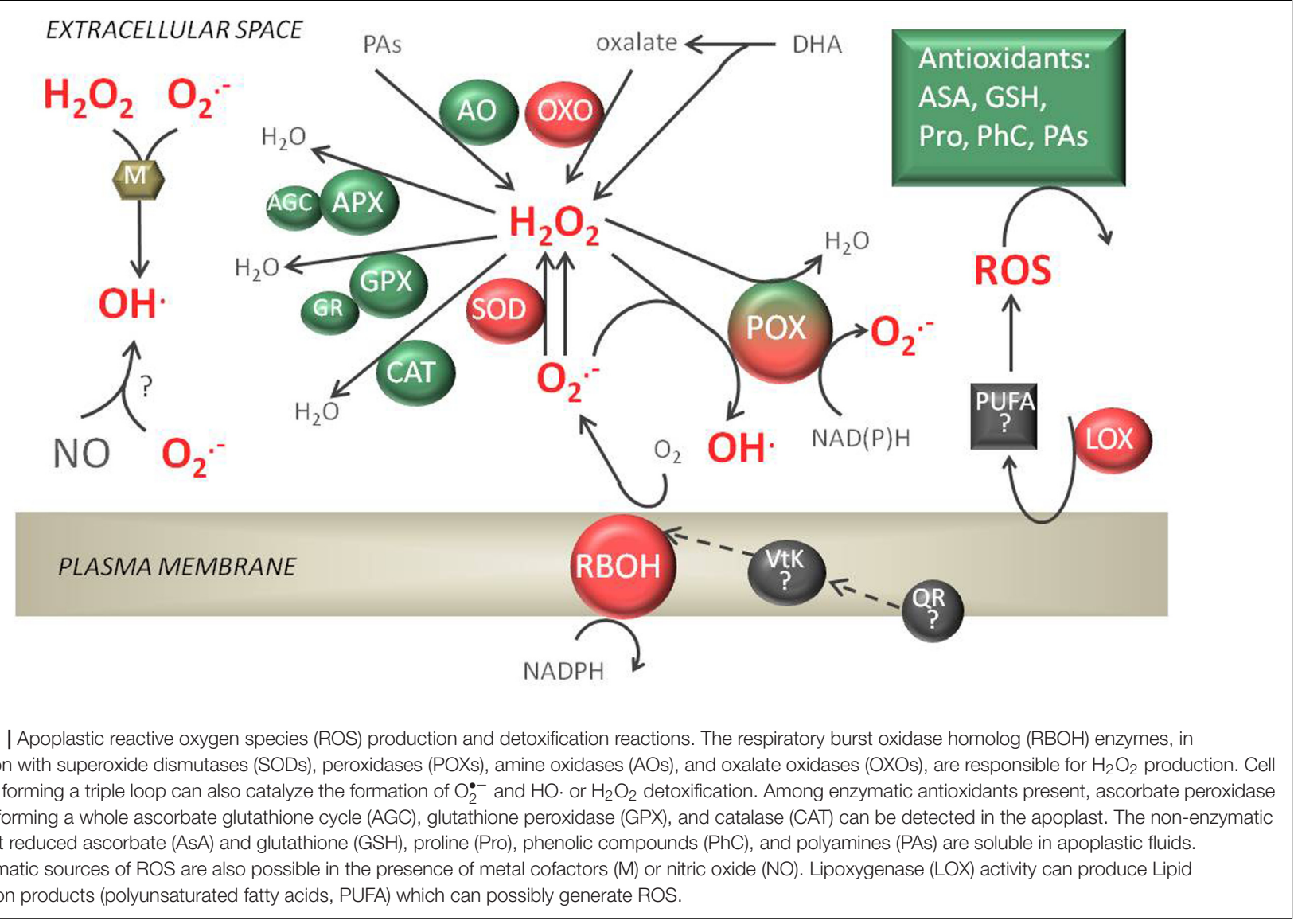

(Li et al., 2016). The best characterized are OXO in Poaceae (Berna and Bernier, 1997), but OXO activity has also been detected in other plants, e.g., in Silene vulgaris (Bringezu et al., 1999). OXOs are Mn-containing oligomeric proteins that catalyze the oxidative breakdown of oxalate into $\mathrm{CO}_{2}$ and $\mathrm{H}_{2} \mathrm{O}_{2}$. All OXOs are characterized by their secondary structure. They are formed as a $\beta$-sheet containing a short internal $\alpha$-helix and a C-terminal $\alpha$-helical region (Membré et al., 1997). Thirty-seven GLP genes were identified in the Arabidopsis genome ( $\mathrm{Li}$ et al., 2016). The presence of GLPs in Arabidopsis was associated with the extracellular matrix; nevertheless, none of the Arabidopsis GLPs have OXO activity (Membré et al., 2000). $\mathrm{H}_{2} \mathrm{O}_{2}$ generated by OXOs is involved in the defense response in certain plantpathogen reactions (Hu et al., 2003).

\section{Amine Oxidases}

Amine oxidases (AOs) include the copper-containing AOs (CuAOs; EC 1.4.3.6) and the flavin-containing polyamine oxidases (PAOs; EC 1.5.3.11). CuAOs catalyze oxidative deamination of aliphatic diamines such as putrescine (Put) and cadaverine (Cad), and less efficiently spermine (Spm) and spermidine (Spd), at the primary amino groups. PAOs are responsible for the oxidation of Spm, Spd, and their acetylated derivatives at the secondary amino group. In both reactions $\mathrm{H}_{2} \mathrm{O}_{2}$ is generated. Arabidopsis contain 10 genes encoding CuAOs, of which only eight encode for putative functional proteins. Among them AtCuAO $\beta$ (At1g62810, previously named AtCuAO1) and AtCuAO $\gamma 1$ (At4g14940, previously ATAO1) are extracellular proteins (Planas-Portell et al., 2013; Tavladoraki et al., 2016). In the Arabidopsis genome, there are five genes encoding PAOs (Tavladoraki et al., 2006), but according to the conducted studies none of these AtPAOs are located in the apoplast (Tavladoraki et al., 2016 and references therein); apoplastic localization of PAOs was shown in barley and maize (Cervelli et al., 2001; Cona et al., 2006).

\section{Other apROS Sources}

In addition to the apROS sources listed above, other mechanisms of apROS production occur in plant tissues (Figure 1). The plant plasmalemma-localized phylloquinone (vitamin K1) can transport electrons from the cytosolic NAD $(\mathrm{P}) \mathrm{H}$ dependent quinone reductase $(\mathrm{QR})$, and it was hypothesized that this vitamin donates electrons to $\mathrm{RBOHs}$ leading to apROS production (Bridge et al., 2000). The non-enzymatic stepwise degradation of ascorbate may also generate ROS (Green and Fry, 2005). Additionally, lipoxygenase (LOX) causes hydroperoxidation of polyunsaturated fatty acids (PUFA) making it an active source of ROS (Das and Roychoudhury, 2014). $\mathrm{OH}$. can be generated in a reaction between nitric oxide (NO) and $\mathrm{O}_{2}^{\bullet-}$, initially generating peroxynitrite $\left(\mathrm{ONOO}^{-}\right)$. $\mathrm{NO}$ is produced in apoplasts from nitrate by plasmalemma-bound nitrate reductase $(\mathrm{PM}-\mathrm{NR})$ and 
nitrite:NO reductase (NI-NOR) (Cohen et al., 2014). Hydroxyl radicals can also be generated in the apoplast in a metal-catalyzed Fenton/Haber-Weiss reaction.

\section{ROS Scavenging in the Apoplast}

Reactive oxygen specie scavenging pathways are responsible for maintaining a low steady-state baseline of ROS. Apoplasts, similar to intracellular cell compartments, are characterized by a specific set of antioxidants (Table 1) that can detoxify all types of ROS produced there (Mittler et al., 2004).

\section{Superoxide Dismutases}

Superoxide dismutases (SODs, EC 1.15.1.1) constitute the first enzymatic defense against ROS; these enzymes convert $\mathrm{O}_{2}^{\bullet-}$ into $\mathrm{H}_{2} \mathrm{O}_{2}$, a less harmful reactant. SODs are classified, according to the metal cofactor used by the enzyme, as iron $(\mathrm{Fe}-)$, manganese $(\mathrm{Mn}-)$, or copper-zinc $(\mathrm{CuZn}-)$ dependent (Kliebenstein et al., 1998; Alscher et al., 2002). A specific set of SOD isozymes is present in all cellular compartments. In Arabidopsis CuZnSOD2 (At2g28190) was identified in EWF by isotope labeling (Bindschedler et al., 2008). Moreover, in a proteomic approach, one of the FeSOD isoforms was found to be an integral protein of the plasma membrane represented by the Arabidopsis gene At5g25100 (Marmagne et al., 2004, 2007).

Superoxide dismutases activity in the apoplast was estimated at only $0.13-2.5 \%$ of symplastic SOD activity; it was also shown that CuZnSOD is the most active apoplastic isoform (Vanacker et al., 1998a,b; Hernández et al., 2001; Kukavica et al., 2005). Moreover, the distribution of CuZnSOD proteins was analyzed in spinach mesophyll cells by immunogold electron microscopy, and revealed that up to $44 \%$ of gold particles were located in the apoplast compared to other cell compartments (Ogawa et al., 1996). Most CuZnSODs are localized in proximity to the plasma membrane, but proteins were also found in the secondary thickening cell wall (Ogawa et al., 1996). Moreover, Ogawa et al. (1997) proposed that CuZnSOD proteins are closely attached to $\mathrm{RBOH}$. Therefore, CuZnSOD may be the major source of $\mathrm{H}_{2} \mathrm{O}_{2}$ in the apoplastic space, after dismutation of $\mathrm{O}_{2}^{\bullet-}$ produced by RBOHs.

\section{Catalases}

Catalases (CATs, EC 1.11.1.6) can directly catalyze a dismutase reaction of two molecules of $\mathrm{H}_{2} \mathrm{O}_{2}$ to water and $\mathrm{O}_{2}$. Catalases are unique among antioxidants since they can decompose ROS without the need for any reductant. The catalase gene family in Arabidopsis is represented by three isozymes, CAT1-3 (Frugoli et al., 1996). Even though the major functional site of CATs are peroxisomes, the isozymes CAT1 (At1g20630) (Bayer et al., 2006) and CAT3 (Atlg20620) (O’Brien et al., 2012a) were also found to be connected with the cell wall. Salguero and Böttger (1995) expected CAT activity to be tightly connected to ROS production by RBOH or POX in the apoplastic space. Catalases have been detected in xylem cell walls of sunflower cotyledons by immunogold electron and immunofluorescence microscopy (Eising et al., 1990) and in isolated cell wall fractions from horseradish (Elstner and Heupel, 1976). It was shown that CAT activity in the apoplast represented only $0.2-2 \%$ of total foliar enzyme activity in barley and oat (Vanacker et al., 1998a,b). Interestingly, in some experiments it was shown that the CAT activity in the apoplastic EWF was about three times higher than that in the soluble symplastic fraction (Parra-Lobato et al., 2009).

\section{Peroxidases}

In the peroxidative cycle POXs catalyze the reduction of $\mathrm{H}_{2} \mathrm{O}_{2}$ by taking electrons from various molecules, mainly phenolic compounds or auxin. Since POXs utilize $\mathrm{H}_{2} \mathrm{O}_{2}$ as a substrate, their catalytic activity reduces $\mathrm{H}_{2} \mathrm{O}_{2}$ levels; therefore, these enzymes can also be considered as antioxidants (Chen and Schopfer, 1999). Apart from the cytosolic fraction, which showed the highest POX activity in tobacco suspension cultures and the liverwort Dumortiera hirsuta, the extracellular space was associated with almost half as much peroxidase activity (Kawano et al., 1998; Li et al., 2010). Among analyzed cell wall fractions, Li et al. (2010) found the highest enzyme activity for loosely bound peroxidases ( $21 \%$ of total activity). However, the activity of POXs bound by hydrophobic interactions, strong electrostatic forces, or covalent linkages should not be ignored. In sunflower seedlings activity of peroxidase ionically bound to the cell wall was higher than that of covalently bound or free apoplastic isozymes (Parra-Lobato et al., 2009). It is possible that during stress conditions, or an apoplastic oxidative burst, some peroxidase isoforms can be released from the cell wall to the apoplast to protect the plants. Since there is such a multiplicity of POX isoforms, it was speculated that these enzymes might show a functional specialization (Cosio and Dunand, 2009). On the basis reported data the proposed functions of individual POXs were listed in the review by Cosio and Dunand (2009) or by Shigeto and Tsutsumi (2016). The regulation of POX activity should be discussed at least at three levels: at the genes expression level and control of protein secretion to apoplast, posttranslational modifications, and substrate specificity in planta. Promoter sequences of Arabidopsis POXs are highly diversified, suggesting specific transcriptional regulation (Francoz et al., 2015). The different pattern of POX expression and/or secretion results in presence or absence of specific isoforms during diverse physiological processes or their localization in different organs. Post-translational regulation of POX activity include: the influence of apoplastic $\mathrm{pH}$ - different isoforms of POX (anionic, cationic, or neutral) may be activated or repressed in that way (Minibayeva et al., 2015; Mangano et al., 2016); protein modification in processes glycosylation and/or phosphorylation (Van Huystee et al., 2004; Mika et al., 2008) and regulation of POX activity by calcium (Carpin et al., 2001). Diversity and availability of POX substrates have also a high impact on POX function in vivo. In vitro POXs have broad substrate specificities, although it is unclear which of these compounds function as substrates in planta (Cosio and Dunand, 2009).

\section{ENZYMES OF THE ASCORBATE-GLUTATHIONE CYCLE}

The combined action of ascorbate peroxidase (APX, EC1.11.1.11), dehydroascorbate reductase (DHAR, EC 1.8.5.1), 
TABLE 1 | Annotation of extracellular localization of antioxidant enzymes.

\begin{tabular}{|c|c|c|c|c|}
\hline Enzyme & Agi & TAIR & SUBA4 & ePLANT \\
\hline FSD1 & At4g25100 & Plasma membrane & $\begin{array}{l}\text { Extracellular: SLP-Local; MS } \\
\text { Plasma membrane: MS }\end{array}$ & $\begin{array}{l}\text { Extracellular: } 12 \\
\text { Plasma membrane: } 50\end{array}$ \\
\hline FSD2 & At5g51100 & No extracellular annotation & Plasma membrane: MS & Plasma membrane : 10 \\
\hline CSD1 & At1g08830 & No extracellular annotation & Extracellular: EpiLoc; PredSL; MS & Extracellular: 14 \\
\hline CSD2 & At2g28190 & apoplast & Extracellular: SubLoc; MS & Extracellular: 2 \\
\hline MSD2 & At3g56350 & No extracellular annotation & $\begin{array}{l}\text { extracellular: Predotar; PredSL; PProwler; iPSORT; } \\
\text { SLP-Local; WoLF PSORT; Target P; YLoc; MS }\end{array}$ & Extracellular: 16 \\
\hline \multicolumn{5}{|c|}{ Ascorbate Peroxidases } \\
\hline APX1 & At1g07890 & No extracellular annotation & Extracellular: MS & Plasma membrane: 30 \\
\hline APX2 & At3g09640 & No extracellular annotation & Extracellular: PredSL & Extracellular: 2 \\
\hline MDHAR3 & At3g09940 & No extracellular annotation & $\begin{array}{l}\text { Extracellular: MS } \\
\text { Plasma membrane: MS }\end{array}$ & No extracellular annotation \\
\hline MDHAR4 & At3g27820 & $\begin{array}{l}\text { Integral component of } \\
\text { membrane }\end{array}$ & $\begin{array}{l}\text { Extracellular: Predotar; PredSL; PProwler; SLPFA; } \\
\text { SLP-Local; BaCelLo; iPSORT } \\
\text { Plasma membrane: MS }\end{array}$ & $\begin{array}{l}\text { Extracellular: } 14 ; \\
\text { Plasma membrane: } 10\end{array}$ \\
\hline MDHAR1 & At3g52880 & $\begin{array}{l}\text { Apoplast, plasma } \\
\text { membrane }\end{array}$ & $\begin{array}{l}\text { Extracellular: MS } \\
\text { Plasma membrane: MS }\end{array}$ & Plasma membrane: 50 \\
\hline MDHAR2 & At5g03630 & No extracellular annotation & $\begin{array}{l}\text { Extracellular: MS } \\
\text { Plasma membrane: MS }\end{array}$ & No extracellular annotation \\
\hline \multicolumn{5}{|c|}{ Dehydroascorbate Reductases } \\
\hline DHAR2 & At1g75270 & Plasma membrane & $\begin{array}{l}\text { Extracellular: AdaBoost; SLPFA } \\
\text { Plasma membrane: MS }\end{array}$ & $\begin{array}{l}\text { Extracellular: } 4 \text {; } \\
\text { Plasma membrane: } 20\end{array}$ \\
\hline \multicolumn{5}{|c|}{ Catalases } \\
\hline CAT1 & At1g20630 & Cell wall & $\begin{array}{l}\text { Extracellular: SLPFA; SubLoc } \\
\text { Plasma membrane: MS }\end{array}$ & $\begin{array}{l}\text { Extracellular: } 4 \text {; } \\
\text { Plasma membrane: } 10\end{array}$ \\
\hline CAT2 & At4g35090 & No extracellular annotation & $\begin{array}{l}\text { Extracellular: SLPFA; SubLoc; MS } \\
\text { Plasma membrane: MS }\end{array}$ & $\begin{array}{l}\text { Extracellular: } 4 \\
\text { Plasma membrane: } 20\end{array}$ \\
\hline CAT3 & At1g20620 & $\begin{array}{l}\text { Apoplast, cell wall, plasma } \\
\text { membrane, }\end{array}$ & $\begin{array}{l}\text { Extracellular: SLPFA } \\
\text { Plasma membrane: MS }\end{array}$ & $\begin{array}{l}\text { Extracellular: } 2 \\
\text { Plasma membrane: } 80\end{array}$ \\
\hline \multicolumn{5}{|c|}{ Glutathione Peroxidases } \\
\hline GPX1 & At2g25080 & No extracellular annotation & Extracellular: MS & No extracellular annotation \\
\hline GPX2 & At2g31570 & Plasma membrane & $\begin{array}{l}\text { Extracellular: PredSL } \\
\text { Plasma membrane: MS }\end{array}$ & $\begin{array}{l}\text { Extracellular: } 2 \\
\text { Plasma membrane: } 10\end{array}$ \\
\hline GPX3 & At2g43350 & No extracellular annotation & $\begin{array}{l}\text { Extracellular: PProwler } \\
\text { Plasma membrane: AdaBoost }\end{array}$ & $\begin{array}{l}\text { Extracellular: } 2 \\
\text { Plasma membrane: } 2\end{array}$ \\
\hline GPX4 & At2g48150 & No extracellular annotation & $\begin{array}{l}\text { Extracellular: PredSL; } \\
\text { SLPFA Plasma membrane: MS }\end{array}$ & $\begin{array}{l}\text { Extracellular: } 4 \\
\text { Plasma membrane: } 10\end{array}$ \\
\hline GPX5 & At3g63080 & Plasma membrane & $\begin{array}{l}\text { Extracellular: PredSL } \\
\text { Plasma membrane: MS }\end{array}$ & $\begin{array}{l}\text { Extracellular: } 2 \\
\text { Plasma membrane: } 60\end{array}$ \\
\hline GPX8 & At1g63460 & No extracellular annotation & $\begin{array}{l}\text { Extracellular: PredSL; } \\
\text { SLPFA; MS }\end{array}$ & Extracellular: 4 \\
\hline
\end{tabular}

The Arabidopsis Information Resource (TAIR) proposes the intracellular localization of enzymes on the basis of literature. The SUBcellular localisation database for Arabidopsis proteins (SUBA4) suggests the localization of enzymes on the basis of different bioinformatics software or mass spectrometry (MS). The Bio-Analytic Resource for Plant Biology (ePLANT) proposes a score for the localization within a plant cell on a heat scale. 


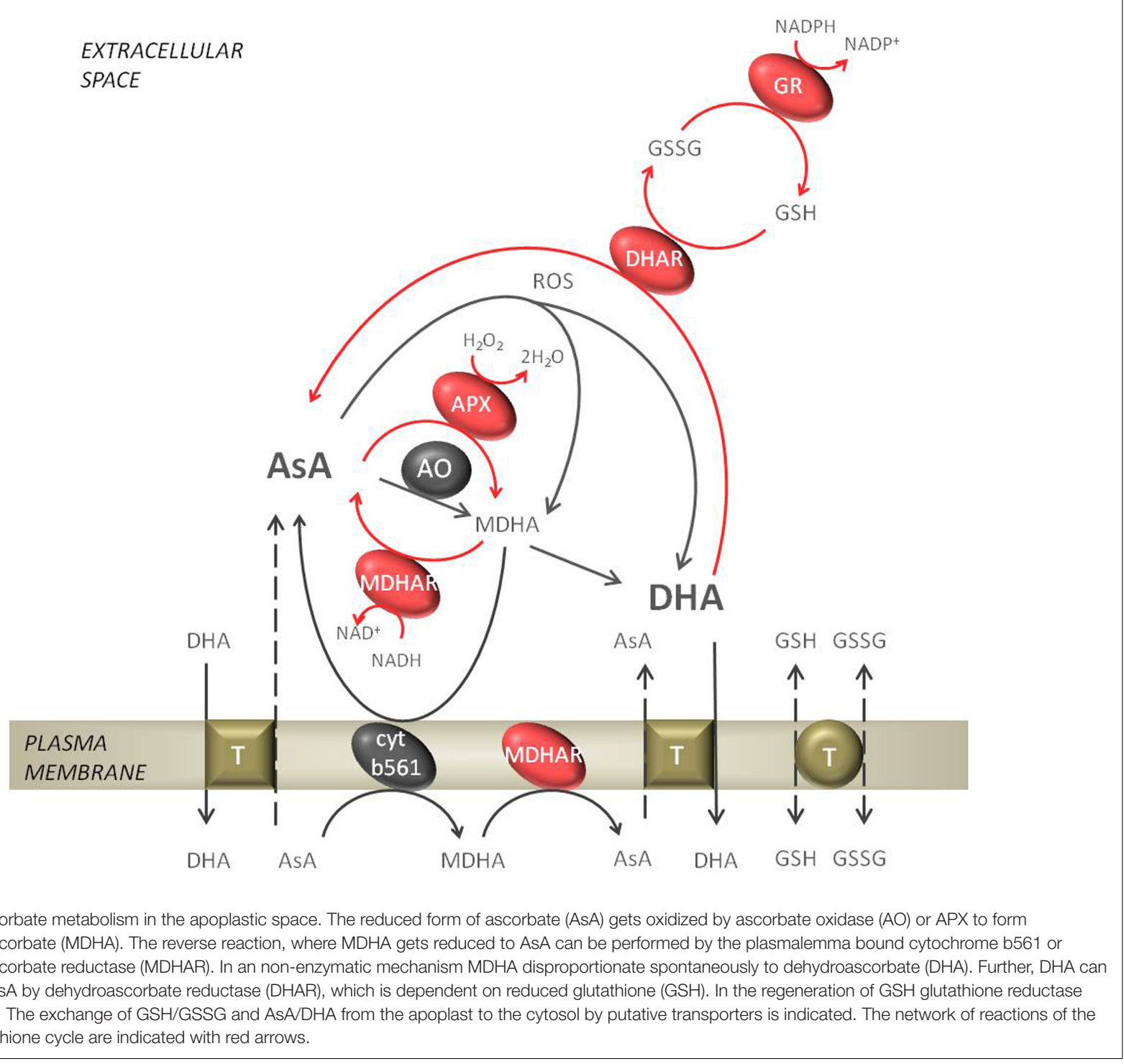

monodehydroascorbate reductase (MDHAR, EC 1.6.5.4), and glutathione reductase (GR, EC 1.6.4.2) can decompose $\mathrm{H}_{2} \mathrm{O}_{2}$ using ascorbate (AsA) and glutathione (GSH) as electron donors, via a pathway called the ascorbate-glutathione cycle (AGC, Figure 2). In the $A G C$ the reduction of $\mathrm{H}_{2} \mathrm{O}_{2}$ is ultimately linked to $\mathrm{NAD}(\mathrm{P}) \mathrm{H}$ oxidation. All AGC enzymes were found in the apoplasts of barley, oat, and pea leaves, but their activity was estimated at only $0.2-2.8 \%$ of symplastic activity (Vanacker et al., 1998a,b; Hernández et al., 2001). However, in the apoplasts of other plants not all AGC enzymes were found to be active; therefore, it is also possible that the whole cycle is not operating in the apoplast, but only certain enzymatic reactions (De Pinto and De Gara, 2004).

The first enzyme of the AGC, APX, is a class I peroxidase that uses AsA as an electron donor to scavenge $\mathrm{H}_{2} \mathrm{O}_{2}$ to water. In the Arabidopsis genome eight types of APX were found, but only APX1 (At1g07890), which is considered a cytosolic enzyme, might also be secreted to the apoplast. APX1 was identified in several reports of extracted plasmalemma or cell wall proteins (Marmagne et al., 2007; O’Brien et al., 2012a). APX showed the highest activity of all AGC enzymes (Diaz-Vivancos et al., 2006), and in roots of sunflower seedlings apoplastic APX activity was even higher than that detected in the soluble symplastic fraction (Parra-Lobato et al., 2009). APX has an even higher affinity for $\mathrm{H}_{2} \mathrm{O}_{2}$ ( $\mu \mathrm{M}$ range) than CATs and class III POXs (mM range).

The regeneration of AsA from its oxidized state is necessary for APX activity. MDHAR is a key enzyme for the recovery of AsA within plant cells, using $\mathrm{NAD}(\mathrm{P}) \mathrm{H}$ directly to reduce monodehydroascorbate (MDHA). The MDHAR multigene family is encoded by the MDHAR1-6 Arabidopsis genes that are targeted to most cellular compartments. Among these proteins MDHAR1 (At3g52880) seems to be localized in organelles and also in the apoplastic space (Bindschedler et al., 2008). Additionally, a plasma membrane-associated MDHAR was found in spinach and identified by NMR (Bérczi and Møller, 1998). 
However, the in vivo localization of MDHAR was shown to be on the cytosolic side of the plasma membrane.

Dehydroascorbate reductase catalyzes the reduction of dehydroascorbate (DHA) to AsA, but the enzyme activity requires $\mathrm{GSH}$ as an electron donor. DHAR is thought to be responsible for the regulation of the symplastic and apoplastic AsA redox state. In Arabidopsis DHAR is encoded by DHAR13 genes. DHAR1 (At1g19570) and DHAR2 (At1g75270) were found to also be associated with the plasma membrane (Marmagne et al., 2007). The reduction of DHA by GR simultaneously results in GSH oxidation.

Glutathione reductase catalyzes the NADPH-dependent reduction of glutathione disulfide (GSSG) to the sulfhydryl form of GSH. GR regenerates GSH and thereby fuels the AGC; therefore, GR is thought to be the rate-limiting step of the cycle. In the apoplast of barley and oat this enzyme has the lowest activity among AGC enzymes in EWF (Vanacker et al., 1998a,b). There seem to be only two genes representing GR in Arabidopsis, GR1 and GR2; however, to date no extracellular isoform has been identified in Arabidopsis.

The in vivo activity of GR and MDHAR in the apoplast remains a matter of debate since their substrate, $\mathrm{NAD}(\mathrm{P}) \mathrm{H}$, seems to be present at very low concentrations in this space. In fact, there is no evidence in the available literature of reduced pyridine nucleotides being extracted from apoplastic fluids. However, the oxidized form of pyridine nucleotides $\left(\mathrm{NAD}^{+}\right)$ which usually constitutes the major amount of nucleotides, was detected in EWF of needles of Norway spruce at a level up to $1.4 \mathrm{nmol} \cdot \mathrm{g}^{-1} \mathrm{DW}$ (Otter and Polle, 1997). O'Brien et al. (2012b) proposed a cycle in which $\mathrm{NADH}$ can be produced, involving the action of apoplastic malate dehydrogenase $(\mathrm{MDH})$ or lactate dehydrogenase $(\mathrm{LDH})$ using $\mathrm{NAD}^{+}$as a substrate.

\section{OTHER EXTRACELLULAR ENZYMATIC ANTIOXIDANTS}

Glutathione peroxidases (GPXs, EC 1.11.1.9) are important for the detoxification of peroxides, such as $\mathrm{H}_{2} \mathrm{O}_{2}$, alkyl hydroperoxides, and peroxynitrite, using GSH as a substrate. In Arabidopsis eight isoforms of GPXs can be found (GPX1-8); of these GPX2 (At2g31570), GPX5 (At3g63080), and GPX6 (At4g11600) were found in the plasma membrane (Marmagne et al., 2007). In sunflower seedlings GPX activity in the apoplast did not account for even $10 \%$ of symplastic enzyme activity (Parra-Lobato et al., 2009). Some peroxidases favor thioredoxin (TRX, EC 1.8.1.9) over GSH as a substrate in their regeneration system. Moreover, in the antioxidative system, 2 further thiol-dependent peroxidases are important: peroxiredoxins (PRXs) and glutaredoxins (GRXs). PRXs are reduced by TRX while GRX reduction depends on reduced GSH. These thiol-based POXs cannot only eliminate hydroxyperoxides, but GPXs, PRXs, and GRXs can revert protein disulfides to dithiols and can therefore protect protein thiols from oxidation. Some of these PRXs and GRXs might be secreted to the extracellular space, but detailed characterization of these enzymes is lacking (Meyer et al., 2008).

\section{Ascorbate}

The reduced form of ascorbate (AsA) can scavenge ROS as a consequence of being oxidized to form MDHA and DHA (Smirnoff, 1996). In the apoplastic space of most plants the ascorbate content was estimated to reach up to $10 \%$ of the total cellular pool and is in the micromolar range (Vanacker et al., 1998a; Pignocchi and Foyer, 2003). The low apoplastic ascorbate content might be connected to AsA degradation in this space. In contrast to cytosolic ascorbate, in the apoplast the pool is generally more oxidized; the quantity of ascorbate in the oxidized state reaches 75-99\% (Takahama and Oniki, 1992; Vanacker et al., 1998a,b; Hernández et al., 2001; De Pinto and De Gara, 2004). Ascorbate can be oxidized by ROS, but the apoplastic enzyme ascorbate oxidase also catalyzes the oxidation reaction of AsA to MDHA (Pignocchi and Foyer, 2003). The resulting MDHA spontaneously disproportionates to AsA and DHA, accelerated by the acidic apoplastic pH (Parsons and Fry, 2012).

The possibility of efficient reduction of extracellular DHA and MDHA is still a matter of debate. It was proposed that the transmembrane protein cytochrome b561 can transfer electrons from cytosolic AsA to extracellular acceptors to reduce MDHA to AsA on the apoplastic side (Horemans et al., 1994). Also plasmalemma-bound MDHAR plays a role in the regeneration of AsA from MDHA (Bérczi and Møller, 1998). Another possibility to reduce apoplastic DHA is via transfer to the symplast and exchange for AsA (Figure 2). Horemans et al. (1998) proposed a model of ascorbate transport at the plasma membrane of higher plant cells involving specific transporters. Maurino et al. (2006) identified in Arabidopsis putative plasmalemma ascorbate transporters sharing similarity with known nucleobase-ascorbate transporters (NATs) from other species. DHA appears to be the preferred form of transport from the apoplast to the cytosol through high-affinity carriers or facilitated diffusion (Smirnoff, 1996). Infiltration of DHA into tobacco cell cultures or leaves of silver birch proved that active transport of ascorbic acid across the plasma membrane is necessary to achieve reduction of DHA occurring inside the cytosol (Potters et al., 2000; Kollist et al., 2001). However, the transport system seems to be too slow to maintain a reduced ascorbate pool in the apoplastic space during high rates of ROS production (Horemans et al., 2000). Therefore, the quest for discerning ascorbate transport systems across the plasma membrane needs definitely further research.

\section{Glutathione}

Glutathione is an abundant tripeptide ( $\gamma$-glutamylcysteinglycine) in plant tissues (reviewed by Noctor et al., 2012). The reduced form of glutathione (GSH) can scavenge all ROS and is itself oxidized to glutathione disulphide (GSSG). Using biochemical methods, glutathione was localized and measured in all cellular compartments, including the apoplast (Vanacker et al., 1998a,b; Hernández et al., 2001); unfortunately the gold particle immunocytochemical method used to label glutathione in the apoplasts of Arabidopsis leaves was below the level of detection (Zechmann et al., 2008). In most plant species, around $1-10 \%$ of the total glutathione pool is present in the apoplastic space. In some plant species, such as barley and pea, the apoplastic pool 
was estimated to be in the micromolar range (Vanacker et al., 1998a,b; Hernández et al., 2001). The low glutathione content in the apoplast might be due to localization of GSSG degradation in this space. Hydrolysis of glutathione is carried out by $g$-glutamyltransferase/transpeptidase (GGT), which is probably bound to the cell wall of plants (Storozhenko et al., 2002). GGT promotes the transfer of glutamate mainly from GSSG to other dipeptides, but also GSH and GS-conjugates can be utilized in a lower extent. In Arabidopsis and other plant species, GGT1 and GGT2 are associated with the cell wall (Ohkama-Ohtsu et al., 2007). Glutathione transport could be accomplished by the oligopeptide transporter (OPT) family, which can transfer GSH, GSSG, and GS-conjugates, among other peptides, across the plasmalemma (Zhang et al., 2004). During the import of glutathione both GSH and GSSG compete for the same carrier transport systems (Zhang et al., 2004). However, the efficiency of glutathione export to the apoplast remains a matter of debate and no putative transporters were identified up to date (Foyer et al., 2001; Noctor and Foyer, 2016). The apoplastic glutathione pool is generally more oxidized than the cytosolic glutathione pool. Approximately $45-55 \%$ of the apoplastic glutathione pool was found to be in the oxidized state (Vanacker et al., 1998a,b; Hernández et al., 2001). Glutathione, similar to ascorbate affects cell cycle progression in plant cells. Exogenous application of GSH stimulates cells undergoing mitosis and might, therefore, promote cell division during hair tip growth of the Arabidopsis root or in tobacco cell suspensions (Sánchez-Fernández et al., 1997; Potters et al., 2004). However, an increased GSSG level does not have a negative effect on cell proliferation, as was reported for DHA (De Pinto et al., 1999).

\section{OTHER ANTIOXIDANTS}

In the apoplast other low-mass antioxidants are also present, such as phenolics and polyamines, which might be important for ROS detoxification. Phenolics are a heterogeneous category of molecules containing a phenol group. Almost 10000 compounds can be assigned to this group, including diverse secondary metabolites. Many of these phenolics (flavonoids, tannins, hydroxycinnamic acid, and lignin) possess antioxidant properties. As electron donors, phenolic compounds can quench ROS because they are easily oxidized, and the resulting phenoxyl radicals are less reactive than oxygen radicals (Kagan and Tyurina, 1998). Polyphenols were tested in vitro and found to be the most efficient low-mass antioxidants in plant cells (more effective than AsA or tocopherols) but were not as effective as SOD (Taubert et al., 2003). Moreover, phenolics are also able to scavenge lipid radicals and prevent the propagation of lipid peroxidation. The major form in which phenolics can be detected is bound to the cell wall (Wallace and Fry, 1994; Hutzler et al., 1998). However, free phenolic compounds were also detected in EWF (Maksimović et al., 2008). Beyond that it was found that the composition of phenolics in the apoplast can change in response to different elicitors (Baker et al., 2015). Phenolics can be released into the apoplastic space either through vesicle-mediated transport or specific membrane transporters, including GST-flavonoid complexes. However, the ROS scavenging capacity of phenolic compounds in the apoplastic space was estimated not to be efficient enough, probably because of the low concentration (Baker and Mock, 2004). It is known that phenols can activate POX activity, since they serve as their substrate. The reaction products - phenoxyl radicals - have to be further detoxified via reduction by AsA. Therefore, phenols that are oxidized by POXs can form a ROS-scavenging phenolic/ASA/POX system, in which the action of MDHAR is also necessary to reduce the resulting MDHA (Takahama and Oniki, 1992). Among phenolic compounds, POXs can utilize flavonoids as their substrate. Flavonoids are one of the major classes of phenolics, with the ability to serve as direct electron donors; therefore, they can scavenge all kinds of ROS (Bors et al., 1990). In plant cells flavonoids can be transported via transporters or vesicles to the apoplast and accumulate mainly within cell walls (Zhao, 2016). Another category of phenolics includes acidic derivatives such as hydroxycinnamic acid and hydroxybenzoic acid. Hydroxycinnamic acid is of great interest because of its antioxidant features (hydrogenor electron-donating ability). Hydroxycinnamic acids (such as ferulic, caffeic, sinapic, and p-coumaric acids) are structural and functional constituents of plant cell walls (Wallace and Fry, 1994). The oxidation of derivatives of hydroxycinnamic acid by peroxidases is one of the features that make them important in the apoplast.

Polyamines were assumed to be protective compounds (Bouchereau et al., 1999). The most abundant plant polyamines include Putrescine, Spermidine, and Spermine. However, the catabolism of polyamines occurs in the apoplast; therefore, their content can be very low or even at undetectable levels. The concentration of different polyamines in EWFs of tobacco and barley was determined to be around 1-10 $\mu \mathrm{M}$ (Marina et al., 2008; Sobieszczuk-Nowicka et al., 2016). Due to their cationic nature at physiological $\mathrm{pH}$, polyamines are able to interact with negatively charged macromolecules in a reversible manner, which suggests that they may be free radical scavengers (Ha et al., 1998; Das and Misra, 2004). However, the oxidative degradation of polyamines in the apoplast by AOs can produce significant quantities of $\mathrm{H}_{2} \mathrm{O}_{2}$; therefore, their role as antioxidants is questionable (Rea et al., 2004). The direct beneficial effect of polyamines for plant development or defense responses is still a matter of research.

The amino acid proline (Pro) is not only an important osmolyte in plant cells, but also an important scavenger of ROS. Pro utilizes $\mathrm{OH}$ - and ${ }^{1} \mathrm{O}_{2}$, and can inhibit the damage caused by the chain reaction of lipid peroxidation (Matysik et al., 2002). The reactivity of Pro with $\mathrm{H}_{2} \mathrm{O}_{2}$ and $\mathrm{O}_{2}^{\bullet-}$ seems very low; therefore, the role of Pro as an efficient cellular antioxidant has been questioned (Kaul et al., 2008). The content of Pro in apoplasts was estimated at around 1-20 $\mu \mathrm{M}$ in the EWF of bean and sugarcane (Tejera et al., 2006; Sobahan et al., 2009).

Some hormones belonging to the indole family show high reactivity with ROS, allowing the indoleamine to function as an electron donor and serve as a trap for ROS chain reactions. Even though these molecules are mostly known 
as mammalian hormones, some indole derivatives, such as tryptophan, melatonin, and auxins, are present in plants. The most prominent mammalian indole is melatonin, and its role as an antioxidant in plants has also been recognized (Arnao and Hernández-Ruiz, 2006). To date, indole derivatives have shown various different biological effects, other than acting as antioxidants. In plants auxins are the most studied among indole derivatives that regulate cell growth (Leyser, 2010). In recent years, their ROS decomposing activity became more apparent, and some indoles are even more active than GSH (Cano et al., 2003). The most valuable feature of indoles is their small size. Moreover, they are both water and lipid soluble; hence these molecules can easily penetrate the plasma membrane, but their antioxidant potential in the apoplast has to be further elucidated.

The plasma membrane has a lipophobic center that most antioxidants cannot enter; therefore, lipid-soluble vitamins are important for membrane protection. Two of the different forms of vitamin $\mathrm{E}$ are tocopherols and tocotrienols. In contrast to other low-mass antioxidants, tocopherols are hydrophobic and lipidsoluble and because of their proximity to membranes tocopherols can therefore protect lipids and other membrane components from lipid peroxidation (Munné-Bosch and Alegre, 2002). Among the $\alpha, \beta, \gamma$, and $\delta$ forms of tocopherols, $\alpha$-tocopherol is most abundant in leaves and is also the most active form (Kaiser et al., 1990). Tocopherols can directly quench ROS, especially ${ }^{1} \mathrm{O}_{2}$ which is irreversibly oxidized. Regeneration of the resulting tocopheroxyl radical to its reduced state is performed by AsA or GSH (Fryer, 1992). Moreover, tocopherols can scavenge lipid peroxyl radicals considerably faster, before they are able to attack the target lipid substrate. The concentration of $\alpha$-tocopherol in membranes is relatively low (less than $2 \mathrm{~mol} / \mathrm{mol}$ phospholipid), and since no transport mechanism of these molecules from plastids (where they are synthesized) has been detected to date, its content in the plasma membrane is questionable. Nevertheless, it was shown that the lack of tocopherols in mutants resulted in cell wall defects such as callose deposition (Maeda et al., 2006).

The electrons from vitamin $\mathrm{K} 1$ might also be used to reduce oxidized lipids in plasma membranes, terminating lipid peroxidation chain reactions. A possible electron acceptor might be cytochrome b561, simultaneously causing AsA regeneration.

The main method to isolate the apoplastic fluids is the infiltration of leaves and extraction of EWF. In previous studies where the concentration of ascorbate and glutathione or antioxidant enzyme activity was determined, it is important to be aware of the possibility of contamination of this EWF fraction with cytosolic components. It is not possible for these low mass antioxidants to freely diffuse through the membranes to the apoplast, but small disruption of the plasma membrane cannot be excluded during the experimental procedure extracting EWF. The presence of glucose 6-phosphate dehydrogenase (G6PDH) activity can be used as a marker for cytoplasmic contamination of EWF. In all the described studies less than $2 \%$ of total extractable foliar G6PDH activity was found in the EWF.

Large scale proteomics of EWF revealed that most proteins are stress-related or cell wall-modifying enzymes (RodríguezCelma et al., 2016); therefore, there is no doubt over the apoplast's function in defense. Nevertheless, a complex antioxidant network has evolved in the apoplastic spaces of plants, although the overall antioxidant defense in this space is generally low compared to that in the intracellular space. The low ROS detoxification capacity in the apoplastic space provides a fast overflow mechanism that allows ROS to accumulate. The aim of this respiratory burst may be the precondition for ROS signaling.

\section{ROS SIGNALING CONNECTING THE APOPLAST WITH THE NUCLEUS}

It is typically assumed that the plasma membrane serves as the first site of perception of environmental changes. Compartment-specific ROS accumulation can activate diverse signal transduction pathways (Figure 3). ROS signaling is not only controlled by ROS production and scavenging; the sequence of events is far more complicated. However, the signaling intermediates between stress perception in the apoplast and the physiological responses are still not fully understood (reviewed by Mittler et al., 2011; Shapiguzov et al., 2012; Baxter et al., 2014; Kangasjärvi and Kangasjärvi, 2014).

When $\mathrm{H}_{2} \mathrm{O}_{2}$ generation in the apoplast exceeds the relatively low scavenging capacity of this space ROS can accumulate. The first possibility is that $\mathrm{H}_{2} \mathrm{O}_{2}$, which is a neutral molecule, can diffuse through the plasma membrane to the cell, boosting the intracellular ROS pool and activating symplastic ROS signaling. Bienert et al. (2007) provided evidence for $\mathrm{H}_{2} \mathrm{O}_{2}$ diffusion through specific aquaporins. The second possibility is that the $\mathrm{H}_{2} \mathrm{O}_{2}$ wave can move within the apoplast from cell to cell of the same tissue (Mittler et al., 2011). For long distance transport ROS can move through the vascular system of plants. It is not surprising that the highest content of $\mathrm{H}_{2} \mathrm{O}_{2}$ within a leaf was detected in veins (Orozco-Cardenas and Ryan, 1999). Therefore, ROS participate in long distance communication, where the information has to be carried systematically and might be transformed into another signal to reach more distant plant organs (Baxter et al., 2014). The speed of the ROS wave was estimated to be approximately $8 \mathrm{~cm} \cdot \mathrm{min}^{-1}$ (Miller et al., 2009).

A major function for RBOHD of responsibility for generating fast-moving ROS signals during stressful conditions was proposed. $\mathrm{RBOH}$ activity is crucial for both long distance ROS signaling and the ROS burst that is transduced to the nucleus. ROS produced by $\mathrm{RBOHs}$ are thought to activate calcium plasma membrane hyperpolarization-activated $\mathrm{Ca}^{2+}$ channels (Foreman et al., 2003). Opening of these channels leads to increases in cytosolic $\mathrm{Ca}^{2+}$ content and causes membrane depolarization (Mittler et al., 2011). In turn, increased symplastic $\mathrm{Ca}^{2+}$ content can activate $\mathrm{RBOH}$ activity by binding the cytosolic EF-hand motif creating a feedback loop (Sagi and Fluhr, 2001). Elevated cytosolic $\mathrm{Ca}^{2+}$ concentrations can initiate further responses via the action of $\mathrm{Ca}^{2+}$-binding proteins. In plant cells these proteins can be considered calcium sensors, including calmodulins (CaMs) and CaM-like proteins (McCormack et al., 2005), calcineurin B-like (CBL) proteins (Luan, 2009), and calcium-dependent protein kinases (CDPKs or CPKs) (Harmon et al., 2000). Similar to ROS, the ubiquitous second messenger $\mathrm{Ca}^{2+}$ seems to be another critical step toward initiating defense 


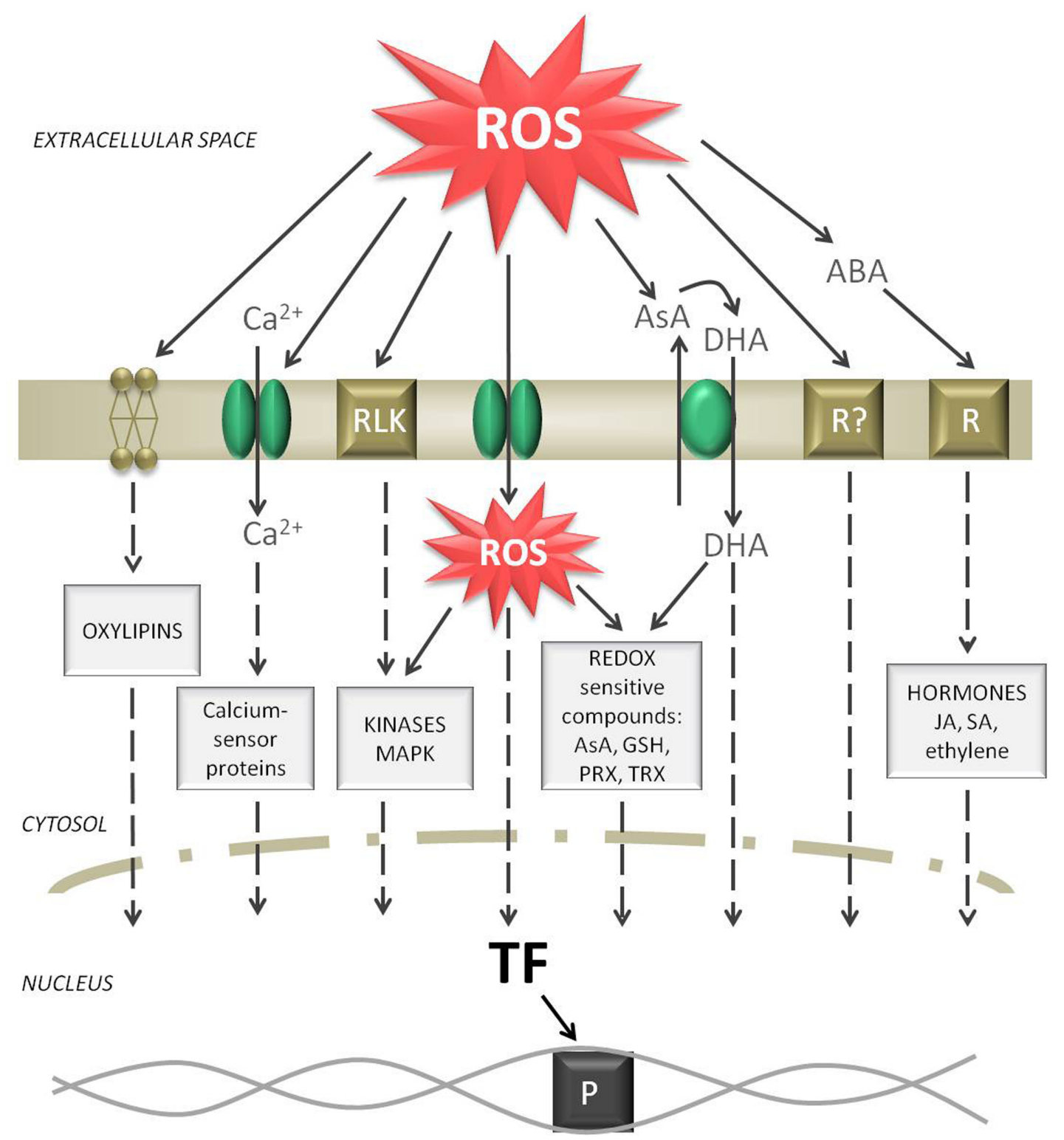

FIGURE 3 | Signaling routes starting from a ROS burst in the apoplast. Elevated ROS levels can oxidize membrane lipids, activate Ca ${ }^{2+}$ channels, activate receptor like kinases (RLK), diffuse through aquaporins, oxidize AsA while producing DHA, activate putative ROS receptors, and induce abscisic acid (ABA) signaling. All these events form separate or common signaling cascades in the cytosol and can finally induce transcription factors (TF). As a result, the reception of a ROS burst in the apoplast can be transferred to induce polymerase $(\mathrm{P})$ and start gene expression in the nucleus.

signaling (Steinhorst and Kudla, 2013). The $\mathrm{Ca}^{2+}$ influx to the cytosol can be accompanied by other ion fluxes through dedicated channels $\left[\mathrm{H}^{+}\right.$pump, anion channel, stelar $\mathrm{K}+$ outward rectifier (SKOR)] or permeable membranes. Hence $\mathrm{H}^{+}$influx and $\mathrm{K}^{+}$or $\mathrm{Cl}^{-}$efflux is one of the earliest responses in ROSmediated signaling. It was shown that $\mathrm{K}^{+}$flow through SKORs is a rapid response to apoplastic $\mathrm{H}_{2} \mathrm{O}_{2}$ (Garcia-Mata et al., 2010). Alterations in ion conductance might be a more general signaling pathway under oxidative stress. Not only the ion balance but also the $\mathrm{pH}$ of the apoplast may vary since the buffering capacity in this compartment is not as efficient as that of the symplast
(Grignon and Sentenac, 1991). The $\mathrm{pH}$ of the apoplast, which is usually between 4.5 and 5.5, may fluctuate in response to external and internal stimuli and signals (Felle, 2001). Changes in extracellular $\mathrm{pH}$ impacts several enzyme activities, for instance cell wall POX. Moreover, a shift in the external $\mathrm{pH}$ was found to be a rapid modulator of plant gene expression (Lager et al., 2010).

The major antioxidants regulate the steady-state level of ROS and therefore determine signal transduction. Since the redox state of ascorbate and glutathione pools is directly linked to ROS levels, these low-mass antioxidants might be a redox link between the apoplast and the cytosol (Sierla et al., 2013). This 
checkpoint might control cell cycle progression, and thereby cell growth, during stressful conditions as indicated by Reichheld et al. (1999). The ascorbate pool is not only the most important low-mass antioxidant but is a well-established element of ROS signaling (Pastori et al., 2003; Pignocchi and Foyer, 2003). Since AsA can be directly oxidized by ROS, the increased levels of DHA in the apoplast can function as signaling molecules. It was shown that the redox state of ascorbate varies throughout the cell cycle phases (Horemans et al., 2000; Pignocchi and Foyer, 2003). Apoplastic ascorbate is engaged in the regulation of the cell cycle (Kato and Esaka, 1999; Potters et al., 2000). It was proposed that increased DHA oxidation in the apoplast and elevated import to the cell can affect cell cycle progression in tobacco cell cultures (De Pinto et al., 1999; Potters et al., 2000). Furthermore, apoplastic DHA seems to inhibit cell proliferation in several plant species (Paciolla et al., 2001; Potters et al., 2004). Moreover, soluble thiol-containing low-molecular-mass compounds, mainly GSH, are important regulatory compounds in plant cells. Li et al. (2013) proposed that extracellular GSH in plants has a similar function to that of a neurotransmitter in animal cells. Moreover, GSH itself was proposed to be an activator of TFs (Tron et al., 2002). There are also several redoxsensitive proteins that operate through switching "on" and "off" depending on the cellular redox state or ROS action. All enzymes that have sulfur residues (particularly PRXs, GRXs, and TRXs) are susceptible to reversible oxidation/reduction (Spadaro et al., 2010). These redox active compounds directly modify cellular metabolism or can further execute their function via downstream signaling components.

When ROS content in the apoplast is not effectively scavenged and exceeds a certain level, it might have a toxic effect and cause tissue damage, such as protein oxidation or nonenzymatic breakdown of lipids. Oxidized PUFAs, which may be embedded in the surface of the cell as free PUFA, represent the first step in the chain reaction of lipid peroxidation. Further lipid peroxidation products from the cellular membrane, called oxylipins, can act as signaling elements (Farmer and Mueller, 2013). ROS can also oxidize extracellular peptides or domains of receptor proteins in the apoplastic space. Putative ROS receptors were speculated to exist, but to date specific apoplastic receptor proteins that can be directly modified by ROS have not been identified (Kangasjärvi and Kangasjärvi, 2014). However, there are many receptor proteins at the outer surface of the plasma membrane, including hormone receptors, innate immune receptors and others that are sensitive to ROS. For instance, animal $G$ protein signaling is also involved in many stress-associated physiological processes in plants. The heterotrimer present in the plasma membrane after perceiving extracellular stimuli, such as apoplastic ROS accumulation, can transfer the signal to the cytosol. It was proposed that $\mathrm{RBOHs}$ received initial signals from $G$ proteins working in the same signaling network. In general, the increased level of apoplastic ROS can be directly monitored by oxidizing putative receptors present in the plasma membrane that can trigger downstream signaling events. Receptor-like kinases (RLKs) in the plasma membrane can be activated by apoplastic ROS. RLKs are cysteine-rich transmembrane proteins that contain an extracellular ligand binding domain and a conserved intracellular protein kinase domain. This could be one of the mechanisms by which extracellular ROS can directly activate intracellular signaling cascades via protein phosphatases and kinases (histidine kinases) (Neill et al., 2002). Reversible protein phosphorylation is a fast signaling mechanism that can amplify the response to ROS (Baxter et al., 2014). The mitogen-activated protein kinase (MAPK) pathway is the most prominent and best studied signaling cascade. These proteins have kinase activity and are thereby interlinked. Phosphorylated (activated) MAPK interacts with and alters the phosphorylation status of target proteins, including TFs, enzymes, and other proteins, ultimately influencing gene expression; specific intermediates are still being identified. Arabidopsis encodes 10 MAPKKKKs, 80 MAPKKKs, 10 MAPKKs, and 23 MAPKs which form complex signaling networks (Jonak et al., 2002). Some kinases were identified as playing specific roles in ROS-mediated signaling; these include the ROS-responsive MAPKKK, MEKK1, MPK3, MPK4, and MPK6 (Colcombet and Hirt, 2008). The application of $\mathrm{H}_{2} \mathrm{O}_{2}$ to Arabidopsis protoplasts was found to activate the phosphorylation cascade involving MPK3 and MPK6 (Kovtun et al., 2000). MEKK1-MPK4 kinase activity is also activated by exogenous $\mathrm{H}_{2} \mathrm{O}_{2}$ treatment of Arabidopsis seedlings (Nakagami et al., 2006). In many conditions, proteins from the WRKY family work downstream of MAPK and can directly activate gene transcription (Eulgem and Somssich, 2007; Chen et al., 2012). A specific characteristic of plant transduction pathways is negative regulation, where a response is induced by inactivating repressor proteins. This mechanism includes protein dephosphorylation or ubiquitination, and only then can transcription proceed. Rosenfeld et al. (2002) suggested that this negative regulation provides a faster transduction system. ROS can also directly oxidize diverse proteins triggering a metabolic response. Some oxidized proteins are targeted to be degraded via the ubiquitination pathway. Other oxidized peptides were found to act directly as signaling molecules. Therefore, the abundance of diverse oxidized proteins may regulate plant responses.

Apoplastic ROS can elicit plant hormone signaling. $\mathrm{H}_{2} \mathrm{O}_{2}$ interaction with specific hormonal compounds, mainly salicylic acid (SA), ethylene, jasmonic acid (JA), and abscisic acid (ABA), is well established (Xia et al., 2015). All these hormones may be perceived by plasmalemma-bound hormone receptors or can further activate gene expression or MAPK signaling (Santner and Estelle, 2009). Most genes that were sensitive to apoplastic ROS were also responsive to ABA signaling (Blomster et al., 2011). ABA is localized in all cellular compartments, but it was shown with immunogold labeling that the apoplast is a major site of free ABA accumulation (Bertrand et al., 1992) or transport (Sauter and Hartung, 2000). ABA has an important role in signal transduction pathways (Wilkinson and Davies, 2002). Most reports have demonstrated that exogenous application of ABA may promote $\mathrm{H}_{2} \mathrm{O}_{2}$ accumulation in the apoplast, which is dependent on $\mathrm{RBOH}$ activity and $\mathrm{Ca}^{2+}$ channels (Kwak et al., 2003; Hu et al., 2005). Interaction of ABA with other hormones was also shown in the regulation of diverse physiological processes, e.g., stomatal closure. JA, SA, and ethylene are considered second messengers in oxidative signal transduction; 
ROS act upstream and downstream of these hormones. On one hand ethylene and SA are generally induced by oxidative bursts, on the other hand ethylene and SA signaling promote enhanced ROS production forming a self-amplifying loop (Watanabe et al., 2001; Rao et al., 2002). Experimental work showed that the application of SA can induce extracellular $\mathrm{O}_{2}^{\bullet-}$ production, which is probably catalyzed by cell wall POX (Kawano et al., 1998; Mori et al., 2001). Auxins can also induce $\mathrm{O}_{2}^{\bullet-}$ production in the apoplast, and subsequent $\mathrm{OH}$. release can promote elongation growth in a POX-dependent reaction (Schopfer et al., 2002). However, JA has the opposite effect than ethylene and SA, acting as an antagonist to in the regulation of different stress responses (Lorenzo and Solano, 2005). Moreover, JA was found to have the ability to reduce $\mathrm{RBOH}$-induced ROS generation (Denness et al., 2011).

All of the elements described above can activate specific TFs in the nucleus. Important TF for intracellular signaling pathways that can be activated in response to ROS can belong to different families including: WRKY, NAC (NAM, ATAF1/2, and CUC2), zinc finger transcription factors (ZAT), basicdomain leucine-zipper proteins (bZIP), heat shock proteins (HSP), and others (Singh et al., 2002; Van Breusegem et al., 2008). ROS are thought to activate TFs via direct oxidation. $\mathrm{H}_{2} \mathrm{O}_{2}, \mathrm{O}_{2}^{\bullet-}$, and ${ }^{1} \mathrm{O}_{2}$ ROS can all induce transcription of specific sets of genes in plant cells (Neill et al., 2002; Gill and Tuteja, 2010). A common TF binding site for all oxidative stress-responsive genes has never been identified, but in several ROS-induced genes specific redox-sensitive promoters have been found by Desikan et al. (2001). More specific cis-regulatory elements (CRE) in gene promoter regions, functioning as binding sites for TFs, have been identified in the Arabidopsis genome using a universal algorithm (Geisler et al., 2006). In this microarray study well-characterized motifs such as the ABAresponsive CRE (ABRE), drought responsive element (DRE), and ethylene responsive element (ERE) were analyzed upon $\mathrm{H}_{2} \mathrm{O}_{2}$ treatment and let to the identification of 128 putative motifs in these functional CRE, that are engaged in abiotic stress signaling.

Extracellular ROS, in particular, can control several genetic defense or developmental programs. Several approaches have been used to simulate ROS production in the apoplastic space in order to reveal the expression of specific genes. A microarray study showed that mainly cellular antioxidant enzymes, but also apoplastic proteins including $\mathrm{RBOHs}$ and ascorbate oxidases, were activated by $\mathrm{H}_{2} \mathrm{O}_{2}$ treatment, while others such as POXs and expansins were downregulated (Stanley Kim et al., 2005). Interestingly, genes that are potentially involved in signaling, including TFs of the WRKY family, were downregulated. Using mass spectrometry Wan and Liu (2008) identified different protein spots in 2DE-gel that were responsive to $\mathrm{H}_{2} \mathrm{O}_{2}$ treatment in rice. Upregulated proteins were mainly engaged in cell defense, redox homeostasis, signal transduction, protein synthesis and degradation, photosynthesis, and carbohydrate/energy metabolism. Rice seedling proteome changes were also analyzed in the apoplasts of roots, revealing that $45 \%$ of proteins that were responsive to $\mathrm{H}_{2} \mathrm{O}_{2}$ treatment were mainly involved in carbohydrate metabolism, redox homeostasis, cell defense, and signal transduction (Zhou et al., 2011). However, it should be kept in mind that exogenous treatment with $\mathrm{H}_{2} \mathrm{O}_{2}$ cannot be compared to in vivo apoplastic ROS generation.

For decades, there has been speculation as to how responses to apoplastic ROS can be so highly specific, since so many levels are engaged in signaling, and coordinated changes in gene expression and optimization of metabolic pathways are involved. This enables optimization of growth and development and survival upon environmental challenges. The ROS burst in the apoplast may be a fast on/off mechanism to induce signaling, but other signaling elements represent the specificity of signaling to different stimuli since these signaling pathways are not linear.

\section{APOPLASTIC ROS METABOLISM DURING ENVIRONMENTAL STRESSES}

Plants have developed diverse mechanisms to perceive and react to abiotic and biotic stresses (Baxter et al., 2014). In particular, an apoplastic ROS burst induced by extracellular stimuli is one of the earliest events in many plant defense responses. Environmental stresses that particularly affect the apoplastic space of plants are explored below.

\section{Ozone}

Ozone $\left(\mathrm{O}_{3}\right)$ exposure is very toxic to plants, and it is therefore considered one of the major air pollutants whose levels are becoming severely dangerous for crop production (Chameides et al., 1994). $\mathrm{O}_{3}$ has a strong oxidizing potential $(+2 \mathrm{eV})$ and can directly cause injury to all cellular compounds. Ozone enters the plant leaf cell through stomata. Since this molecule is so reactive, it cannot penetrate deep into the cells; therefore, the direct site of action for $\mathrm{O}_{3}$ has been suggested to be the apoplast. This stress factor is often considered a model for apoplastic ROS generation (Baier et al., 2005). The mode of $\mathrm{O}_{3}$ action in the apoplast can be either direct, due to the strong chemical reactivity of this molecule, or indirect due to production of other ROS. The toxicity of $\mathrm{O}_{3}$ can be greatly enhanced by its spontaneous decomposition to ROS in aqueous environments like that of the apoplast. Ozone can act as an abiotic elicitor inducing an oxidative burst in the apoplastic space. Two hours after sunflower plants were exposed to $\mathrm{O}_{3}, \mathrm{H}_{2} \mathrm{O}_{2}$ deposits were detected in the apoplast by cytochemical staining (Ranieri et al., 2003). This ROS accumulation was probably connected to increased $\mathrm{RBOH}$ and POX activity.

In the apoplast unsaturated fatty acids in the membrane are the first to be oxidized during the ozonolysis process, therefore $\mathrm{O}_{3}$-induced lipid peroxidation is a major consequence. In further steps, lipid oxidation products decompose to form organic radicals, and ROS are also produced as byproducts. One of the consequences of ozone action is plasma membrane permeability and ion leakage. Other air pollutants, such as $\mathrm{SO}_{2}$ and $\mathrm{NO}_{2}$, are also dangerous to plants.

\section{Heavy Metals}

Depending on their oxidation states, heavy metals, such as $\mathrm{Cd}, \mathrm{Mo}, \mathrm{Ni}, \mathrm{Zn}$, and $\mathrm{Al}$, can be highly reactive and toxic for 
TABLE 2 | Impact of changes in apROS-producing enzyme expression on development and metabolism of Arabidopsis plants (examples).

\begin{tabular}{|c|c|c|c|}
\hline Enzyme & Changes in gene expression & Developmental/metabolic effect & Reference \\
\hline \multicolumn{4}{|l|}{ NADPH Oxidases } \\
\hline $\mathrm{RBOHC}$ & $\downarrow$ At5g51060 & $\begin{array}{l}\text { Stunted roots, short root hairs, defect in setting up the tip-high } \\
\text { calcium gradient in root hairs }\end{array}$ & $\begin{array}{l}\text { Foreman et al., 2003; } \\
\text { Monshausen et al., 2007; } \\
\text { Takeda et al., } 2008\end{array}$ \\
\hline $\mathrm{RBOHD}$ & $\downarrow$ At5g47910 & $\begin{array}{l}\text { Smaller rosette size; enhanced accumulation coumarin and } \\
\text { scopoletin in response to pathogen treatment; decreased } \\
\text { accumulation of callose in response to elicitor; suppression of } \\
\text { jasmonic acid-responsive genes; inability to mediate rapid systemic } \\
\text { response; higher sensitivity aphid infection }\end{array}$ & $\begin{array}{l}\text { Galletti et al., 2008; Miller } \\
\text { et al., 2009; Maruta et al., } \\
\text { 2011; Chaouch et al., } 2012\end{array}$ \\
\hline RBOHF & $\downarrow$ At1g64060 & $\begin{array}{l}\text { Delayed accumulation of salicylic acid in response to pathogen } \\
\text { treatment; decreased APX1 transcript level suppression of jasmonic } \\
\text { acid-responsive genes }\end{array}$ & $\begin{array}{l}\text { Maruta et al., 2011; } \\
\text { Chaouch et al., } 2012\end{array}$ \\
\hline $\mathrm{RBOHH} / \mathrm{RBOHJ}$ & $\downarrow$ At5g60010/ $\downarrow$ At3g45810 & Reduced fertility; pollen tube collapse & Lassig et al., 2014 \\
\hline \multicolumn{4}{|l|}{ Peroxidases } \\
\hline POX2 or POX25 & $\downarrow$ At1g05250 or $\downarrow$ At2g41480 & $\begin{array}{l}\text { Lower dry-weight of the main stem; decreased lignin content and } \\
\text { altered lignin structure }\end{array}$ & Shigeto et al., 2013, 2015 \\
\hline POX34 & $\downarrow$ At3g49120 & $\begin{array}{l}\text { Reduced callose deposition in response to microbe-associated } \\
\text { molecular patterns; diminished expression of flagellin-responsive } \\
\text { genes }\end{array}$ & Daudi et al., 2012 \\
\hline POX37 & $\uparrow A t 4 g 08770$ & $\begin{array}{l}\text { Dwarfism; smaller leaf surface; delay on growth of the flower stems; } \\
\text { reduction in root length and secondary root development; increase } \\
\text { in phenolic compounds of cell wall }\end{array}$ & Pedreira et al., 2011 \\
\hline POX53 & $\downarrow$ At5g06720 & $\begin{array}{l}\text { Longer hypocotyl; increased susceptibility to nematode; } \\
\text { three-carpel silique phenotype }\end{array}$ & Jin et al., 2011 \\
\hline POX57 & $\uparrow A t 5 g 17820$ & $\begin{array}{l}\text { Dwarfism; increased callose deposit in response to bacterial } \\
\text { elicitors; increased resistance to nectrotrophic pathogens and } \\
\text { higher sensitivity to hemibiotroph pathogens; impaired cutin } \\
\text { biosynthesis }\end{array}$ & $\begin{array}{l}\text { Lu et al., 2014; Survila } \\
\text { et al., } 2016\end{array}$ \\
\hline \multirow[t]{2}{*}{ POX 71} & $\downarrow$ At5g64120 & Enhanced biomass; longer hypocotyls; increased cell area & Raggi et al., 2015 \\
\hline & $\uparrow A t 5 g 64120$ & Reduction of biomass; reduction of cell size & \\
\hline \multicolumn{4}{|l|}{ Amine Oxiades } \\
\hline AtCuAOß (CuAO1) & $\downarrow$ At1g62810 & $\begin{array}{l}\text { Impaired NO production; lower sensitivity to exogenous ABA; lower } \\
\text { expression of stress-responsive genes in response to ABA } \\
\text { treatment }\end{array}$ & Wimalasekera et al., 2011 \\
\hline
\end{tabular}

plants. When plant roots are exposed to heavy metals they are absorbed into the cells. As a first line of defense plants reduce uptake into root cells by restricting metal ions to the apoplast, binding them to the cell wall, or by inhibiting long distance transport. Therefore, the apoplast functions to accumulate heavy metals to protect intracellular metabolism and prevent the plant from suffering toxicity effects (Brune et al., 1995). Probably the most dangerous characteristic of some redox active transition metals, such as $\mathrm{Cu}^{+}, \mathrm{Fe}^{2+}$, and $\mathrm{Mn}^{2+}$ which have unpaired electrons, is their participation in the Fenton/Haber-Weiss reaction. Therefore, the most frequently documented and earliest consequence during heavy metal exposure is the overproduction of ROS in the apoplast of many plants (Pourrut et al., 2007; Zhang F. et al., 2009; Źróbek-Sokolnik et al., 2009). Increased expression of RBOHs or LOXs were frequently observed during heavy metal stress including Cd, Cu, Zn (Remans et al., 2010, 2012; Cuypers et al., 2011). On the other hand, heavy metals can inactivate important enzymes by binding to their cysteine residues or displacing cofactors. Hence, the accumulation of metals can affect activities of antioxidant enzymes, such as POXs (Kimura et al., 2014), SODs, or CATs in the apoplast, and their inactivation can be dangerous for the plants (Bhaduri and Fulekar, 2012). Moreover, heavy metals can initiate peroxidation of membrane lipids. Another dangerous feature of heavy metals that are loaded to the apoplast is that they can be immobilized in cell walls. Some of these metals may displace $\mathrm{Ca}^{2+}$ from the cell walls affecting their structure.

\section{Water Deficit}

Water deficit is a common stress factor and can be observed during drought, salinity, and chilling stress which all create the problem of low water availability for plants. A water deficit initially causes loss of free water in the apoplasts of plants (Kar, 2011). This change in water content in the apoplast may impact on ROS concentrations in this space, directly affecting apROS homeostasis (Noctor et al., 2014). During water deficit plants avoid transpirational loss of water by closing stomata. It is known that stomatal movement is regulated by ion fluxes through the plasma membrane and also by hormone and ROS signaling (Munemasa et al., 2013). It was proposed that apoplastic ROS accumulation actively participates in the initiation of stomatal closure. Hence, ROS accumulation in the apoplasts of plants was 
observed during salinity and drought stress, which is probably connected to increased RBOH activities (Hernández et al., 2001; Evans et al., 2016).

\section{Temperature Stress}

Changes in environmental temperatures directly affect plasma membrane stability. In response to heat stress an increased membrane fluidity can activate putative $\mathrm{Ca}^{2+}$ channel, which is one of the primary heat sensors in plants (Gong et al., 1998; Saidi et al., 2009). The induction of these $\mathrm{Ca}^{2+}$ channels leads to an increase in cytosolic calcium level. The influx of $\mathrm{Ca}^{2+}$ to the cytosol activates $\mathrm{RBOH}$ by promoting its phosphorylation (Saidi et al., 2010). It was shown that the knockout for RBOHD in Arabidopsis mutants impairs heat tolerance (Larkindale et al., 2005). As a consequence heat stress is accompanied by $\mathrm{RBOH}$-dependent ROS generation at the plasma membrane (Königshofer et al., 2008). The ROS burst in the heat shock response can further lead to the induction among other signaling elements the activation of HSP (Kotak et al., 2007). HSPs are the most important stress proteins toward heat stress tolerance, because they act as chaperones and function in protecting proteins (Sun and Guo, 2016).

Chilling stress provides membrane destabilization and its dysfunction. Furthermore, freezing temperatures result in extracellular crystal formation affecting apoplastic metabolism. $\mathrm{RBOH}$-dependent ROS formation in the apoplast was observed in response to cold stress (Zhou et al., 2012). The consequences of cold stress can be oxidative damage to lipids, protein, and other macromolecules.

\section{Pathogen Attack}

Plant pathogens have developed diverse mechanisms to invade plant tissues. To penetrate into the cell pathogens first have to digest the cell wall, which is the main barrier. Other pathogens can penetrate plant cells through stomata. During both plantpathogen interactions the apoplast is the first compartment that is in contact with the pathogen. In the plasmalemma plants have specific receptors (pattern recognition receptors; PRRs) that recognize pathogen elicitors - the so-called pathogen associated molecular pattern (PAMPs) (Monaghan and Zipfel, 2012). Immediately after recognition of a pathogen infection, plants activate signaling cascades and defense responses. One of the common protective mechanisms of plants is the hypersensitivity response (HR) in which local cell death occurs at the site of infection. An oxidative burst, mainly performed by RBOHs, is one of the earliest events in the HR. In 1983, Doke detected strong $\mathrm{O}_{2}^{\bullet-}$ generation in potato tubers prior to HR elicited by Phytophthora infestans and tobacco mosaic virus. Increased ROS production in response to pathogens was expected to occur due to RBOH and POX activities (Bolwell et al., 2001). A major ROS outbreak close to the pathogen may on one hand kill the pathogen directly, and on the other hand can damage the tissue of the host inhibiting spread of the pathogen.

The first action of a pathogen is to secrete diverse lytic enzymes that can further digest the cell wall. Therefore, one of the plant defense mechanisms during pathogen invasion is cross linkage of cell walls. Stiff wall polymers (lignins or callose) can protect the walls from degradation. Plant POXs are widely known to function in cross linkage of wall polymers. In the case of pathogen attack, most antioxidants do not work against the invader but are important in ROS/redox signaling cascades. In the fight against the pathogen plants can very rapidly produce specific toxins, hydrolytic enzymes, pathogenesis-related proteins, and other substances.

Interestingly most environmental stresses that are not directly connected to the apoplast, such as strong light, ion imbalance, and wounding, can also affect apoplastic ROS metabolism. Increased ROS levels have been frequently observed during exposure to all these stresses. Microarray data showed that almost all stresses can induce $\mathrm{RBOH}$ expression in plants (Suzuki et al., 2012). Intracellular signaling can probably connect cellular stresses to trigger apoplastic ROS production. It was proposed that ROS production in organelles can trigger $\mathrm{RBOH}-$ dependent systemic signaling. For instance, it was observed that the impairment of mitochondrial complex I in the frostbite mutant, which led to oxidative stress in mitochondria, also affected apoplastic ROS metabolism (Podgórska et al., 2015). Mitochondrial or chloroplastic ROS generation during metabolic fluctuations can induce ROS production in extracellular spaces. The interplay between the apoplast and organelles needs further research.

\section{CONCLUSION}

Further research is needed to understand apROS metabolism in detail. In this review, we have tried to emphasize how important this specific aspect is for plant metabolism. ApROS are produced and detoxified in enzymatic and non-enzymatic reaction depending on numerous factors, including apoplast $\mathrm{pH}$, metal ion concentration, or availability of metabolites in the extracellular space. ApROS allow rearrangements of the cell wall, and in consequence the growth of plants. Products of apROS metabolism regulate the rate of cells division. The apoplast is the first place to receive signals coming from the outside, and apROS are involved in both local defense and the signal transmission into the cell and other plant organs. The results of experiments performed using plants with altered expression of apROS producing enzymes (Table 2) clearly indicate the importance of apROS in plant development and plant-pathogen interaction. It can be assumed that genetic manipulation of the expression of enzymes involved in apROS metabolism may allow the breeding of crop plants more resistant to pathogens, with greater biomass, or a desired lignin profile. However, it should be noted that apROS metabolism is a very complex multi-piece puzzle. Changing one of its elements may not lead to the desired effect because of (i) the multitude of enzyme isoforms (e.g., $10 \mathrm{RBOHs}$ and over 70 isoforms of POX exist in Arabidopsis) that can take over its functions, (ii) individual compound cross-regulation (action of RBOHs can be regulated by POX activity), and (iii) the opposing reactions in which they are involved (e.g., POXs are ROS-producing and ROS-detoxifying enzymes; polyamines are antioxidants but also substrates for ROS- producing enzymes). 


\section{AUTHOR CONTRIBUTIONS}

$\mathrm{AP}, \mathrm{MB}$, and $\mathrm{BS}$ wrote the manuscript. All authors read and approved the manuscript.

\section{REFERENCES}

Alscher, R. G., Erturk, N., and Heath, L. S. (2002). Role of superoxide dismutases (SODs) in controlling oxidative stress in plants. J. Exp. Bot. 53, 1331-1341. doi: $10.1093 /$ jexbot/53.372.1331

Arnao, M. B., and Hernández-Ruiz, J. (2006). The physiological function of melatonin in plants. Plant Signal. Behav. 1, 89-95. doi: 10.4161/psb.1.3.2640

Baier, M., Kandlbinder, A., Golldack, D., and Dietz, K. J. (2005). Oxidative stress and ozone: perception, signalling and response. Plant Cell Environ. 28, 1012-1020. doi: 10.1111/j.1365-3040.2005.01326.x

Baker, C. J., and Mock, N. M. (2004). A method to detect oxidative stress by monitoring changes in the extracellular antioxidant capacity in plant suspension cells. Physiol Mol. Plant Pathol. 64, 255-261. doi: 10.1016/j.pmpp. 2004.09.004

Baker, C. J., Mock, N. M., Smith, J. M., and Aver'yanov, A. A. (2015). The dynamics of apoplast phenolics in tobacco leaves following inoculation with bacteria. Front. Plant Sci. 6:649. doi: 10.3389/fpls.2015.00649

Barceló, A. R., and Laura, V. G. R. (2009). "Reactive oxygen species in plant cell walls," in Reactive Oxygen Species in Plant Signaling, eds L. A. del Río and A. Puppo (Berlin: Springer), 73-93.

Baxter, A., Mittler, R., and Suzuki, N. (2014). ROS as key players in plant stress signalling. J. Exp. Bot. 65, 1229-1240. doi: 10.1093/jxb/ert375

Bayer, E. M., Bottrill, A. R., Walshaw, J., Vigouroux, M., Naldrett, M. J., Thomas, C. L., et al. (2006). Arabidopsis cell wall proteome defined using multidimensional protein identification technology. Proteomics 6, 301-311. doi: 10.1002/pmic.200500046

Bérczi, A., and Møller, I. M. (1998). NADH-Monodehydroascorbate oxidoreductase is one of the redox enzymes in spinach leaf plasma membranes. Plant Physiol. 116, 1029-1036. doi: 10.1104/pp.116. 3.1029

Berna, A., and Bernier, F. (1997). Regulated expression of a wheat germin gene in tobacco: oxalate oxidase activity and apoplastic localization of the heterologous protein. Plant Mol. Biol. 33, 417-429. doi: 10.1023/a:10057450 15962

Bertrand, S., Benhamou, N., Nadeau, P., Dostaler, D., and Gosselin, A. (1992). Immunogold localization of free abscisic acid in tomato root cells. Can. J. Bot. 70, 1001-1011. doi: 10.1139/b92-124

Bhaduri, A. M., and Fulekar, M. H. (2012). Antioxidant enzyme responses of plants to heavy metal stress. Rev. Environ. Sci. Biotechnol. 11, 55-69. doi: 10.1007/ s11157-011-9251-x

Bienert, G. P., Møller, A. L., Kristiansen, K. A., Schulz, A., Møller, I. M., Schjoerring, J. K., et al. (2007). Specific aquaporins facilitate the diffusion of hydrogen peroxide across membranes. J. Biol. Chem. 282, 1183-1192. doi: 10.1074/jbc. M603761200

Bindschedler, L. V., Palmblad, M., and Cramer, R. (2008). Hydroponic isotope labelling of entire plants (HILEP) for quantitative plant proteomics; an oxidative stress case study. Phytochemistry 69, 1962-1972. doi: 10.1016/j. phytochem.2008.04.007

Blomster, T., Salojärvi, J., Sipari, N., Brosché, M., Ahlfors, R., Keinänen, M., et al. (2011). Apoplastic reactive oxygen species transiently decrease auxin signaling and cause stress-induced morphogenic response in Arabidopsis. Plant Physiol. 157, 1866-1883. doi: 10.1104/pp.111.181883

Bolwell, G. P., Butt, V. S., Davies, D. R., and Zimmerlin, A. (1995). The origin of the oxidative burst in plants. Free Radical Res. 23, 517-532. doi: 10.3109/ 10715769509065273

Bolwell, P. P., Page, A., Piślewska, M., and Wojtaszek, P. (2001). Pathogenic infection and the oxidative defences in plant apoplast. Protoplasma 217, 20-32. doi: 10.1007/BF01289409

Bors, W., Heller, W., Michel, C., and Saran, M. (1990). Flavonoids as antioxidants: determination of radical-scavenging efficiencies. Methods Enzymol. 186, 343-355. doi: 10.1016/0076-6879(90)86128-I

\section{ACKNOWLEDGMENT}

This work was supported by Grant 2014/13/B/NZ3/00847 from the National Science Centre (NCN, Poland) given to BS.

Bouchereau, A., Aziz, A., Larher, F., and Martin-Tanguy, J. (1999). Polyamines and environmental challenges: recent development. Plant Sci. 140, 103-125. doi: 10.1016/S0168-9452(98)00218-0

Bridge, A., Barr, R., and Morrè, D. J. (2000). The plasma membrane NADH oxidase of soybean has vitamin K1 hydroquinone oxidase activity. Biochim. Biophys. Acta 1463, 448-458. doi: 10.1016/S0005-2736(99)00239-4

Bringezu, K., Lichtenberger, O., Leopold, I., and Neumann, D. (1999). Heavy metal tolerance of Silene vulgaris. J. Plant Physiol. 154, 536-546. doi: 10.1016/S01761617(99)80295-8

Brune, A., Urbach, W., and Dietz, K. J. (1995). Differential toxicity of heavy metals is partly related to a loss of preferential extraplasmic compartmentation: a comparison of Cd-, Mo-, Ni- and Zn-Stress. New Phytol. 129, 403-409. doi: 10.1111/j.1469-8137.1995.tb04310.x

Cano, A., Alcaraz, O., and Arnao, M. B. (2003). Free radical-scavenging activity of indolic compounds in aqueous and ethanolic media. Anal. Bioanal. Chem. 376, 33-37. doi: 10.1007/s00216-003-1848-7

Carpin, S., Crèvecoeur, M., de Meyer, M., Simon, P., Greppin, H., and Penel, C. (2001). Identification of a Ca2+-pectate binding site on an apoplastic peroxidase. Plant Cell 13, 511-520. doi: 10.1105/tpc.13.3.511

Cervelli, M., Cona, A., Angelini, R., Polticelli, F., Federico, R., and Mariottini, P. (2001). A barley polyamine oxidase isoform with distinct structural features and subcellular localization. Eur. J. Biochem. 268, 3816-3830. doi: 10.1046/j.14321327.2001.02296.x

Chameides, W. L., Kasibhatla, P. S., Yienger, J., and Levy, H. II (1994). Growth of continental-scale metro-agro-plexes, regional ozone pollution, and world food production. Science 264, 74-77. doi: 10.1126/science.264. 5155.74

Chaouch, S., Queval, G., and Noctor, G. (2012). AtRbohF is a crucial modulator of defence-associated metabolism and a key actor in the interplay between intracellular oxidative stress and pathogenesis responses in Arabidopsis. Plant J. 69, 613-627. doi: 10.1111/j.1365-313X.2011.04816.x

Chen, L., Song, Y., Li, S., Zhang, L., Zou, C., and Yu, D. (2012). The role of WRKY transcription factors in plant abiotic stresses. Biochim. Biophys. Acta 1819, 120-128. doi: 10.1016/j.bbagrm.2011.09.002

Chen, S. X., and Schopfer, P. (1999). Hydroxyl-radical production in physiological reactions. Eur. J. Biochem. 260, 726-735. doi: 10.1046/j.1432-1327.1999.00199.x

Cohen, M. F., Gurung, S., Fukuto, J. M., and Yamasaki, H. (2014). Controlled free radical attack in the apoplast: a hypothesis for roles of $\mathrm{O}, \mathrm{N}$ and $\mathrm{S}$ species in regulatory and polysaccharide cleavage events during rapid abscission by Azolla. Plant Sci. 217, 120-126. doi: 10.1016/j.plantsci.2013. 12.008

Colcombet, J., and Hirt, H. (2008). Arabidopsis MAPKs: a complex signalling network involved in multiple biological processes. Biochem. J. 413, 217-226. doi: 10.1042/BJ20080625

Cona, A., Rea, G., Angelini, R., Federico, R., and Tavladoraki, P. (2006). Functions of amine oxidases in plant development and defence. Trends Plant Sci. 11, 80-88. doi: 10.1016/j.tplants.2005.12.009

Cosio, C., and Dunand, C. (2009). Specific functions of individual class III peroxidase genes. J. Exp. Bot. 60, 391-408. doi: 10.1093/jxb/ern318

Cuypers, A., Smeets, K., Ruytinx, J., Opdenakker, K., Keunen, E., Remans, T., et al. (2011). The cellular redox state as a modulator in cadmium and copper responses in Arabidopsis thaliana seedlings. J. Plant Physiol. 168, 309-316. doi: 10.1016/j.jplph.2010.07.010

Das, K., and Roychoudhury, A. (2014). Reactive oxygen species (ROS) and response of antioxidants as ROS-scavengers during environmental stress in plants. Front. Environ. Sci. 2:53. doi: 10.3389/fenvs.2014.00053

Das, K. C., and Misra, H. P. (2004). Hydroxyl radical scavenging and singlet oxygen quenching properties of polyamines. Mol. Cell. Biochem. 262, 127-133. doi: 10.1023/B:MCBI.0000038227.91813.79

Daudi, A., Cheng, Z., O’Brien, J. A., Mammarella, N., Khan, S., Ausubel, F. M., et al. (2012). The apoplastic oxidative burst peroxidase in Arabidopsis is 
a major component of pattern-triggered immunity. Plant Cell 24, 275-287. doi: 10.1105/tpc.111.093039

De Pinto, M. C., and De Gara, L. (2004). Changes in the ascorbate metabolism of apoplastic and symplastic spaces are associated with cell differentiation. J. Exp. Bot. 55, 2559-2569. doi: 10.1093/jxb/erh253

De Pinto, M. C., Francis, D., and De Gara, L. (1999). The redox state of the ascorbate-dehydroascorbate pair as a specific sensor of cell division in tobacco BY-2 cells. Protoplasma 209, 90-97. doi: 10.1007/BF01415704

Denness, L., McKenna, J. F., Segonzac, C., Wormit, A., Madhou, P., Bennett, M., et al. (2011). Cell wall damage-induced lignin biosynthesis is regulated by a reactive oxygen species- and jasmonic acid-dependent process in Arabidopsis. Plant Physiol. 156, 1364-1374. doi: 10.1104/pp.111.175737

Desikan, R., A-H-Mackerness, S., Hancock, J. T., and Neill, S. J. (2001). Regulation of the Arabidopsis transcriptome by oxidative stress. Plant Physiol. 127, 159-172. doi: 10.1104/pp.127.1.159

Desikan, R., Hancock, J., and Neill, S. (2005). "Reactive oxygen species as signalling molecules," in Antioxidants and Reactive Oxygen Species in Plants, ed. N. Smirnoff (Oxford: Blackwell Publishing Ltd), 169-196.

Diaz-Vivancos, P., Rubio, M., Mesonero, V., Periago, P. M., Barceló, A. R., Martínez-Gómez, P., et al. (2006). The apoplastic antioxidant system in Prunus: response to long-term plum pox virus infection. J. Exp. Bot. 57, 3813-3824. doi: $10.1093 /$ jxb/erl138

Eising, R., Trelease, R. N., and Ni, W. (1990). Biogenesis of catalase in glyoxysomes and leaf-type peroxisomes of sunflower cotyledons. Arch. Biochem. Biophys. 278, 258-264. doi: 10.1016/0003-9861(90)90256-X

Elstner, E. F., and Heupel, A. (1976). Formation of hydrogen peroxide by isolated cell walls from horseradish (Armoracia lapathifolia Gilib.). Planta 130, 175-180. doi: 10.1007/BF00384416

Eulgem, T., and Somssich, I. E. (2007). Networks of WRKY transcription factors in defense signaling. Curr. Opin. Plant Biol. 10, 366-371. doi: 10.1016/j.pbi.2007. 04.020

Evans, M. J., Choi, W. G., Gilroy, S., and Morris, R. J. (2016). A ROS-assisted calcium wave dependent on AtRBOHD and TPC1 propagates the systemic response to salt stress in Arabidopsis roots. Plant Physiol. 171, 1771-1784. doi: $10.1104 /$ pp. 16.00215

Farmer, E. E., and Mueller, M. J. (2013). ROS-mediated lipid peroxidation and RESactivated signaling. Annu. Rev. Plant Biol. 64, 429-450. doi: 10.1146/annurevarplant-050312-120132

Felle, H. H. (2001). pH: signal and messenger in plant cells. Plant Biol. 3, 577-591. doi: $10.1055 /$ s-2001-19372

Foreman, J., Demidchik, V., Bothwell, J. H., Mylona, P., Miedema, H., Torres, M. A., et al. (2003). Reactive oxygen species produced by NADPH oxidase regulate plant cell growth. Nature 422, 442-446. doi: 10.1038/nature 01485

Foyer, C. H., Theodoulou, F. L., and Delrot, S. (2001). The functions of interand intracellular glutathione transport systems in plants. Trends Plant Sci. 6, 486-492. doi: 10.1016/S1360-1385(01)02086-6

Francoz, E., Ranocha, P., Nguyen-Kim, H., Jamet, E., Burlat, V., and Dunand, C. (2015). Roles of cell wall peroxidases in plant development. Phytochemistry 112, 15-21. doi: 10.1016/j.phytochem.2014.07.020

Frugoli, J. A., Zhong, H. H., Nuccio, M. L., McCourt, P., McPeek, M. A., Thomas, T. L., et al. (1996). Catalase is encoded by a multigene family in Arabidopsis thaliana (L.) Heynh. Plant Physiol. 112, 327-336. doi: 10.1104/pp.112. 1.327

Fryer, M. J. (1992). The antioxidant effects of thylakoid Vitamin E ( $\alpha$-tocopherol). Plant Cell Environ. 15, 381-392. doi: 10.1111/j.1365-3040.1992.tb00988.x

Galletti, R., Denoux, C., Gambetta, S., Dewdney, J., Ausubel, F. M., De Lorenzo, G., et al. (2008). The AtrbohD-mediated oxidative burst elicited by oligogalacturonides in Arabidopsis is dispensable for the activation of defense responses effective against Botrytis cinerea. Plant Physiol. 148, 1695-1706. doi: $10.1104 /$ pp.108.127845

Garcia-Mata, C., Wang, J., Gajdanowicz, P., Gonzalez, W., Hills, A., Donald, N., et al. (2010). A minimal cysteine motif required to activate the SKOR K+ channel of Arabidopsis by the reactive oxygen species H2O2. J. Biol. Chem. 285, 29286-29294. doi: 10.1074/jbc.M110.141176

Geisler, M., Kleczkowski, L. A., and Karpinski, S. (2006). A universal algorithm for genome-wide in silicio identification of biologically significant gene promoter putative cis-regulatory-elements; identification of new elements for reactive oxygen species and sucrose signaling in Arabidopsis. Plant J. 45, 384-398. doi: 10.1111/j.1365-313X.2005.02634.x

Gill, S. S., and Tuteja, N. (2010). Reactive oxygen species and antioxidant machinery in abiotic stress tolerance in crop plants. Plant Physiol. Biochem. 48, 909-930. doi: 10.1016/j.plaphy.2010.08.016

Gong, M., Van der Luit, A. H., Knight, M. R., and Trewavas, A. J. (1998). Heatshock-induced changes in intracellular $\mathrm{Ca} 2+$ level in Tobacco seedlings in relation to thermotolerance. Plant Physiol. 116, 429-437. doi: 10.1104/pp.116. 1.429

Green, M. A., and Fry, S. C. (2005). Vitamin C degradation in plant cells via enzymatic hydrolysis of 4-O-oxalyl-L-threonate. Nature 433, 83-87. doi: $10.1038 /$ nature 03172

Grignon, C., and Sentenac, H. (1991). pH and ionic conditions in the apoplast. Annu. Rev. Plant Physiol. Plant Mol. Biol. 42, 103-128. doi: 10.1146/annurev. pp.42.060191.000535

Ha, H. C., Sirisoma, N. S., Kuppusamy, P., Zweier, J. L., Woster, P. M., and Casero, R. A. Jr. (1998). The natural polyamine spermine functions directly as a free radical scavenger. Proc. Natl. Acad. Sci. U.S.A. 95, 11140-11145. doi: 10.1073/ pnas.95.19.11140

Halliwell, B. (2006). Reactive species and antioxidants. Redox biology is a fundamental theme of aerobic life. Plant Physiol. 141, 312-322. doi: 10.1104/ pp.106.077073

Harmon, A. C., Gribskov, M., and Harper, J. F. (2000). CDPKs - a kinase for every Ca2+ signal? Trends Plant Sci. 5, 154-159.

Hernández, J. A., Ferrer, M. A., Jiménez, A., Barceló, A. R., and Sevilla, F. (2001). Antioxidant systems and $\mathrm{O} 2 .-/ \mathrm{H} 2 \mathrm{O} 2$ production in the apoplast of pea leaves. Its relation with salt-induced necrotic lesions in minor veins. Plant Physiol. 127, 817-831. doi: 10.1104/pp.010188

Horemans, N., Asard, H., and Caubergs, R. J. (1994). The role of ascorbate free radical as an electron acceptor to cytochrome 6-mediated trans-plasma membrane electron transport in higher plants. Plant Physiol. 104, 1455-1458. doi: $10.1104 /$ pp.104.4.1455

Horemans, N., Asard, H., Van Gestelen, P., and Caubergs, R. J. (1998). Facilitated diffusion drives transport of oxidised ascorbate molecules into purified plasma membrane vesicles of Phaseolus vulgaris. Physiol. Plant. 104, 783-789. doi: 10.1034/j.1399-3054.1998.1040439.x

Horemans, N., Foyer, C. H., and Asard, H. (2000). Transport and action of ascorbate at the plant plasma membrane. Trends Plant Sci. 5, 263-267. doi: 10.1016/S1360-1385(00)01649-6

Hu, X., Bidney, D. L., Yalpani, N., Duvick, J. P., Crasta, O., Folkerts, O., et al. (2003). Overexpression of a gene encoding hydrogen peroxide-generating oxalate oxidase evokes defense responses in sunflower. Plant Physiol. 133, 170-181. doi: 10.1104/pp.103.024026

$\mathrm{Hu}$, X., Jiang, M., Zhang, A., and Lu, J. (2005). Abscisic acid-induced apoplastic $\mathrm{H} 2 \mathrm{O} 2$ accumulation up-regulates the activities of chloroplastic and cytosolic antioxidant enzymes in maize leaves. Planta 223, 57-68. doi: 10.1007/s00425005-0068-0

Hutzler, P., Fischbach, R., Heller, W., Jungblut, T. P., Reuber, S., Schmitz, R., et al. (1998). Tissue localization of phenolic compounds in plants by confocal laser scanning microscopy. J. Exp. Bot. 49, 953-965. doi: 10.1093/jxb/49. 323.953

Jin, J., Hewezi, T., and Baum, T. J. (2011). Arabidopsis peroxidase AtPRX53 influences cell elongation and susceptibility to Heterodera schachtii. Plant Signal. Behav. 6, 1778-1786. doi: 10.4161/psb.6.11. 17684

Jonak, C., Okrész, L., Bögre, L., and Hirt, H. (2002). Complexity, cross talk and integration of plant MAP kinase signalling. Curr. Opin. Plant Biol. 5, 415-424. doi: 10.1016/S1369-5266(02)00285-6

Kadota, Y., Shirasu, K., and Zipfel, C. (2015). Regulation of the NADPH oxidase RBOHD during plant immunity. Plant. Cell Physiol. 56, 1472-1480. doi: $10.1093 /$ pcp/pcv063

Kagan, V. E., and Tyurina, Y. Y. (1998). Recycling and redox cycling of phenolic antioxidants. Ann. N. Y. Acad. Sci. 854, 425-434. doi: 10.1111/j.1749-6632.1998. tb09921.x

Kaiser, S., Di Mascio, P., Murphy, M. E., and Sies, H. (1990). Physical and chemical scavenging of singlet molecular oxygen by tocopherols. Arch. Biochem. Biophys. 277, 101-108. doi: 10.1016/0003-9861(90) 90556-E 
Kangasjärvi, S., and Kangasjärvi, J. (2014). Towards understanding extracellular ROS sensory and signaling systems in plants. Adv. Bot. 2014, 10. doi: 10.1155/ 2014/538946

Kar, R. K. (2011). Plant responses to water stress: role of reactive oxygen species. Plant Signal. Behav. 6, 1741-1745. doi: 10.4161/psb.6.11.17729

Kärkönen, A., and Kuchitsu, K. (2015). Reactive oxygen species in cell wall metabolism and development in plants. Phytochemistry 112, 22-32. doi: 10.1016/j.phytochem.2014.09.016

Kato, N., and Esaka, M. (1999). Changes in ascorbate oxidase gene expression and ascorbate levels in cell division and cell elongation in tobacco cells. Physiol. Plant. 105, 321-329. doi: 10.1034/j.1399-3054.1999.105218.x

Kaul, S., Sharma, S. S., and Mehta, I. K. (2008). Free radical scavenging potential of L-proline: evidence from in vitro assays. Amino Acids 34, 315-320. doi: $10.1007 / \mathrm{s} 00726-006-0407-\mathrm{x}$

Kaur, G., Sharma, A., Guruprasad, K., and Pati, P. K. (2014). Versatile roles of plant NADPH oxidases and emerging concepts. Biotechnol. Adv. 32, 551-563. doi: 10.1016/j.biotechadv.2014.02.002

Kawano, T., Sahashi, N., Takahashi, K., Uozumi, N., and Muto, S. (1998). Salicylic acid induces extracellular superoxide generation followed by an increase in cytosolic calcium ion in tobacco suspension culture: the earliest events in salicylic acid signal transduction. Plant Cell Physiol. 39, 721-730. doi: 10.1093/ oxfordjournals.pcp.a029426

Kawarazaki, T., Kimura, S., Iizuka, A., Hanamata, S., Nibori, H., Michikawa, M., et al. (2013). A low temperature-inducible protein AtSRC2 enhances the ROSproducing activity of NADPH oxidase AtRbohF. Biochim. Biophys. Acta 1833, 2775-2780. doi: 10.1016/j.bbamcr.2013.06.024

Kawasaki, T., Henmji, K., Ono, E., Hatakeyama, S., Iwano, M., Satoh, H., et al. (1999). The small GTP-binding protein Rac is a regulator of cell deth in plants. Proc. Natl. Acad. Sci. U.S.A. 96, 10922-10926. doi: 10.1073/pnas.96.19.10922

Kimura, M., Umemoto, Y., and Kawano, T. (2014). Hydrogen peroxideindependent generation of superoxide by plant peroxidase: hypotheses and supportive data employing ferrous ion as a model stimulus. Front. Plant Sci. 5:285. doi: $10.3389 /$ fpls.2014.00285

Kimura, S., Kawarazaki, T., Nibori, H., Michikawa, M., Imai, A., Kaya, H., et al. (2013). The CBL-interacting protein kinase CIPK26 is a novel interactor of Arabidopsis NADPH oxidase AtRbohF that negatively modulates its ROSproducing activity in a heterologous expression system. J. Biochem. 153, 191-195. doi: 10.1093/jb/mvs132

Kimura, S., Kaya, H., Kawarazaki, T., Hiraoka, G., Senzaki, E., Michikawa, M., et al. (2012). Protein phosphorylation is a prerequisite for the Ca2+-dependent activation of Arabidopsis NADPH oxidases and may function as a trigger for the positive feedback regulation of $\mathrm{Ca} 2+$ and reactive oxygen species. Biochim. Biophys. Acta 1823, 398-405. doi: 10.1016/j.bbamcr.2011.09.011

Kliebenstein, D. J., Monde, R. A., and Last, R. L. (1998). Superoxide dismutase in Arabidopsis: an eclectic enzyme family with disparate regulation and protein localization. Plant Physiol. 118, 637-650. doi: 10.1104/pp.118.2.637

Kollist, H., Moldau, H., Oksanen, E., and Vapaavuori, E. (2001). Ascorbate transport from the apoplast to the symplast in intact leaves. Physiol. Plant 113, 377-383. doi: 10.1034/j.1399-3054.2001.1130311.x

Königshofer, H., Tromballa, H. W., and Löppert, H. G. (2008). Early events in signalling high-temperature stress in tobacco BY2 cells involve alterations in membrane fluidity and enhanced hydrogen peroxide production. Plant Cell Environ. 31, 1771-1780. doi: 10.1111/j.1365-3040.2008.01880.x

Kotak, S., Larkindale, J., Lee, U., von Koskull-Doring, P., Vierling, E., and Scharf, K. D. (2007). Complexity of the heat stress response in plants. Curr. Opin. Plant Biol. 10, 310-316. doi: 10.1016/j.pbi.2007.04.011

Kovtun, Y., Chiu, W. L., Tena, G., and Sheen, J. (2000). Functional analysis of oxidative stress-activated mitogen-activated protein kinase cascade in plants. Proc. Natl. Acad. Sci. U.S.A. 97, 2940-2945. doi: 10.1073/pnas.97. 6.2940

Kukavica, B., Vucinić, Z., and Vuletić, M. (2005). Superoxide dismutase, peroxidase, and germin-like protein activity in plasma membranes and apoplast of maize roots. Protoplasma 226, 191-197. doi: 10.1007/s00709-005-0112-8

Kwak, J. M., Mori, I. C., Pei, Z. M., Leonhardt, N., Torres, M. A., Dangl, J. L., et al. (2003). NADPH oxidase AtrbohD and AtrbohF genes function in ROSdependent ABA signaling in Arabidopsis. EMBO J. 22, 2623-2633. doi: 10.1093/ emboj/cdg277
Lager, I., Andréasson, O., Dunbar, T. L., Andreasson, E., Escobar, M. A., and Rasmusson, A. G. (2010). Changes in external pH rapidly alter plant gene expression and modulate auxin and elicitor responses. Plant Cell Environ. 33, 1513-1528. doi: 10.1111/j.1365-3040.2010.02161.x

Larkindale, J., Hall, J. D., Knight, M. R., and Vierling, E. (2005). Heat stress phenotypes of Arabidopsis mutants implicate multiple signaling pathways in the acquisition of thermotolerance. Plant Physiol. 138, 882-897. doi: 10.1104/ pp. 105.062257

Lassig, R., Gutermuth, T., Bey, T. D., Konrad, K. R., and Romeis, T. (2014). Pollen tube NAD (P) H oxidases act as a speed control to dampen growth rate oscillations during polarized cell growth. Plant J. 78, 94-106. doi: 10.1111/tpj. 12452

Leyser, O. (2010). The power of auxin in plants. Plant Physiol. 154, 501-505. doi: $10.1104 /$ pp.110.161323

Li, F., Wang, J., Ma, C., Zhao, Y., Wang, Y., Hasi, A., et al. (2013). Glutamate receptor-like channel3.3 is involved in mediating glutathionetriggered cytosolic calcium transients, transcriptional changes, and innate immunity responses in Arabidopsis. Plant Physiol. 162, 1497-1509. doi: 10.1104/pp.113.217208

Li, J. L., Sulaiman, M., Beckett, R. P., and Minibayeva, F. V. (2010). Cell wall peroxidases in the liverwort Dumortiera hirsuta are responsible for extracellular superoxide production, and can display tyrosinase activity. Physiol. Plant. 138, 474-484. doi: 10.1111/j.1399-3054.2009.01318.x

Li, L., Xu, X., Chen, C., and Shen, Z. (2016). Genome-wide characterization and expression analysis of the germin-like protein family in rice and Arabidopsis. Int. J. Mol. Sci. 17, 1622. doi: 10.3390/ijms17101622

Lorenzo, O., and Solano, R. (2005). Molecular players regulating the jasmonate signalling network. Curr. Opin. Plant Biol. 8, 532-540. doi: 10.1016/j.pbi.2005. 07.003

Lu, D., Wang, T., Persson, S., Mueller-Roeber, B., and Schippers, J. H. (2014). Transcriptional control of ROS homeostasis by KUODA1 regulates cell expansion during leaf development. Nat. Commun. 5:3767. doi: 10.1038/ ncomms4767

Luan, S. (2009). The CBL-CIPK network in plant calcium signaling. Trends Plant Sci. 14, 37-42. doi: 10.1016/j.tplants.2008.10.005

Maeda, H., Song, W., Sage, T. L., and DellaPenna, D. (2006). Tocopherols play a crucial role in low-temperature adaptation and Phloem loading in Arabidopsis. Plant Cell 18, 2710-2732. doi: 10.1105/tpc.105.039404

Maksimović, J. D., Maksimović, V., Živanović, B., Šukalović, V. H., and Vuletić, M. (2008). Peroxidase activity and phenolic compounds content in maize root and leaf apoplast, and their association with growth. Plant Sci. 175, 656-662. doi: $10.1016 /$ j.plantsci.2008.06.015

Mangano, S., Juárez, S. P. D., and Estevez, J. M. (2016). ROS regulation of polar growth in plant cells. Plant Physiol. 171, 1593-1605. doi: 10.1104/pp.16.00191

Marina, M., Maiale, S. J., Rossi, F. R., Romero, M. F., Rivas, E. I., Gárriz, A., et al. (2008). Apoplastic polyamine oxidation plays different roles in local responses of tobacco to infection by the necrotrophic fungus Sclerotinia sclerotiorum and the biotrophic bacterium Pseudomonas viridiflava. Plant Physiol. 147, 2164-2178. doi: 10.1104/pp.108.122614

Marino, D., Dunand, C., Puppo, A., and Pauly, N. (2012). A burst of plant NADPH oxidases. Trends Plant Sci. 17, 9-15. doi: 10.1016/j.tplants.2011.10.001

Marmagne, A., Ferro, M., Meinnel, T., Bruley, C., Kuhn, L., Garin, J., et al. (2007). A high content in lipid-modified peripheral proteins and integral receptor kinases features in the arabidopsis plasma membrane proteome. Mol. Cell. Proteomics 6, 1980-1996. doi: 10.1074/mcp.M700099-MCP200

Marmagne, A., Rouet, M. A., Ferro, M., Rolland, N., Alcon, C., Joyard, J., et al. (2004). Identification of new intrinsic proteins in Arabidopsis plasma membrane proteome. Mol. Cell. Proteomics 3, 675-691. doi: 10.1074/mcp.M400001-MCP200

Maruta, T., Inoue, T., Tamoi, M., Yabuta, Y., Yoshimura, K., Ishikawa, T., et al. (2011). Arabidopsis NADPH oxidases, AtrbohD and AtrbohF, are essential for jasmonic acid-induced expression of genes regulated by MYC2 transcription factor. Plant Sci. 180, 655-660. doi: 10.1016/j.plantsci.2011. 01.014

Matysik, J., Alia, B. B., and Mohanty, P. (2002). Molecular mechanism of quenching of reactive oxygen species by proline under stress in plants. Curr. Sci. 82, $525-532$. 
Maurino, V. G., Grube, E., Zielinski, J., Schild, A., Fischer, K., and Flügge, U. I. (2006). Identification and expression analysis of twelve members of the nucleobase-ascorbate transporter (NAT) gene family in Arabidopsis thaliana. Plant Cell Physiol. 47, 1381-1393. doi: 10.1093/pcp/pcl011

McCormack, E., Tsai, Y. C., and Braam, J. (2005). Handling calcium signaling: Arabidopsis CaMs and CMLs. Trends Plant Sci. 10, 383-389. doi: 10.1016/j. tplants.2005.07.001

Membré, N., Berna, A., Neutelings, G., David, A., David, H., Staiger, D., et al. (1997). cDNA sequence, genomic organization and differential expression of three Arabidopsis genes for germin/oxalate oxidase-like proteins. Plant Mol. Biol. 35, 459-469. doi: 10.1023/a:1005833028582

Membré, N., Bernier, F., Staiger, D., and Berna, A. (2000). Arabidopsis thaliana germin-like proteins: common and specific features point to a variety of functions. Planta 211, 345-354. doi: 10.1007/s004250000277

Meyer, Y., Siala, W., Bashandy, T., Riondet, C., Vignols, F., and Reichheld, J. P. (2008). Glutaredoxins and thioredoxins in plants. Biochim. Biophys. Acta 1783, 589-600. doi: 10.1016/j.bbamcr.2007.10.017

Mika, A., Buck, F., and Lüthje, S. (2008). Membrane-bound class III peroxidases: identification, biochemical properties and sequence analysis of isoenzymes purified from maize (Zea mays L.) roots. J. Proteomics 71, 412-424. doi: 10.1016/j.jprot.2008.06.006

Miller, G., Schlauch, K., Tam, R., Cortes, D., Torres, M. A., Shulaev, V., et al. (2009). The plant NADPH oxidase RBOHD mediates rapid systemic signaling in response to diverse stimuli. Sci. Signal. 2:ra45. doi: 10.1126/scisignal.2000448

Minibayeva, F., Beckett, P. R., and Kranner, I. (2015). Roles of apoplastic peroxidases in plant response to wounding. Phytochemistry 112, 122-129. doi: 10.1016/j.phytochem.2014.06.008

Mittler, R., Vanderauwera, S., Gollery, M., and Van Breusegem, F. (2004). Reactive oxygen gene network of plants. Trends Plant Sci. 9, 490-498. doi: 10.1016/j. tplants.2004.08.009

Mittler, R., Vanderauwera, S., Suzuki, N., Miller, G., Tognetti, V. B., Vandepoele, K., et al. (2011). ROS signaling: the new wave? Trends Plant Sci. 16, 300-309. doi: $10.1016 /$ j.tplants.2011.03.007

Monaghan, J., and Zipfel, C. (2012). Plant pattern recognition receptor complexes at the plasma membrane. Curr. Opin. Plant Biol. 15, 349-357. doi: 10.1016/j.pbi. 2012.05.006

Monshausen, G. B., Bibikova, T. N., Messerli, M. A., Shi, C., and Gilroy, S. (2007). Oscillations in extracellular $\mathrm{pH}$ and reactive oxygen species modulate tip growth of Arabidopsis root hairs. Proc. Natl. Acad. Sci. U.S.A. 104, 20996-21001. doi: 10.1073/pnas.0708586104

Morel, J., Fromentin, J., Blein, J. P., Simon-Plas, F., and Elmayan, T. (2004). Rac regulation of NtrbohD, the oxidase responsible for the oxidative burst in elicited tobacco cell. Plant J. 37, 282-293. doi: 10.1046/j.1365-313X.2003. 01957.x

Mori, I. C., Pinontoan, R., Kawano, T., and Muto, S. (2001). Involvement of superoxide generation in salicylic acid-induced stomatal closure in Vicia faba. Plant Cell Physiol. 42, 1383-1388. doi: 10.1093/pcp/pce176

Müller, K., Carstens, A. C., Linkies, A., Torres, M. A., and Leubner-Metzger, G. (2009). The NADPH-oxidase AtrbohB plays a role in Arabidopsis seed afterripening. New Phytol. 184, 885-897. doi: 10.1111/j.1469-8137.2009.03005.x

Munemasa, S., Muroyama, D., Nagahashi, H., Nakamura, Y., Mori, I. C., and Murata, Y. (2013). Regulation of reactive oxygen species-mediated abscisic acid signaling in guard cells and drought tolerance by glutathione. Front. Plant Sci. 4:472. doi: 10.3389/fpls.2013.00472

Munné-Bosch, S., and Alegre, L. (2002). The function of tocopherols and tocotrienols in plants. Crit. Rev. Plant Sci. 21, 31-57. doi: 10.1080/0735260291044179

Nagawa, S., Xu, T., and Yang, Z. (2010). RHO GTPase in plants: conservation and invention of regulators and effectors. Small GTPases 1, 78-88. doi: 10.4161/sgtp. 1.2.14544

Nakagami, H., Soukupová, H., Schikora, A., Zárský, V., and Hirt, H. (2006). A Mitogen-activated protein kinase kinase kinase mediates reactive oxygen species homeostasis in Arabidopsis. J. Biol. Chem. 281, 38697-38704. doi: 10.1074/jbc.M605293200

Neill, S. J., Desikan, R., Clarke, A., Hurst, R. D., and Hancock, J. T. (2002). Hydrogen peroxide and nitric oxide as signalling molecules in plants. J. Exp. Bot. 53, 1237-1247. doi: 10.1093/jexbot/53.372.1237
Noctor, G., and Foyer, C. H. (2016). Intracellular redox compartmentation and ROS-related communication in regulation and signaling. Plant Physiol. 171, 1581-1592. doi: 10.1104/pp.16.00346

Noctor, G., Mhamdi, A., Chaouch, S., Han, Y., Neukermans, J., Marquez-Garcia, B., et al. (2012). Glutathione in plants: an integrated overview. Plant Cell Environ. 35, 454-484. doi: 10.1111/j.1365-3040.2011.02400.x

Noctor, G., Mhamdi, A., and Foyer, C. H. (2014). The roles of reactive oxygen metabolism in drought: not so cut and dried. Plant Physiol. 164, 1636-1648. doi: $10.1104 /$ pp.113.233478

O’Brien, J. A., Daudi, A., Butt, V. S., and Bolwell, G. P. (2012b). Reactive oxygen species and their role in plant defence and cell wall metabolism. Planta 236, 765-779. doi: 10.1007/s00425-012-1696-9

O’Brien, J. A., Daudi, A., Finch, P., Butt, V. S., Whitelegge, J. P., Souda, P., et al. (2012a). A peroxidase-dependent apoplastic oxidative burst in cultured Arabidopsis cells functions in MAMP-elicited defense. Plant Physiol. 158, 2013-2027. doi: 10.1104/pp.111.190140

Oda, T., Hashimoto, H., Kuwabara, N., Akashi, S., Hayashi, K., Kojima, C., et al. (2010). Structure of the N-terminal regulatory domain of a plant NADPH oxidase and its functional implications. J. Biol. Chem. 285, 1435-1445. doi: 10.1074/jbc.m109.058909

Ogawa, K., Kanematsu, S., and Asada, K. (1996). Intra- and extra-cellular localization of "cytosolic" CuZn-superoxide dismutase in spinach leaf and hypocotyl. Plant Cell Physiol. 37, 790-799. doi: 10.1093/oxfordjournals.pcp. a029014

Ogawa, K., Kanematsu, S., and Asada, K. (1997). Generation of superoxide anion and localization of $\mathrm{CuZn}$-superoxide dismutase in the vascular tissue of spinach hypocotyls: their association with lignification. Plant Cell Physiol. 38, 1118-1126. doi: 10.1093/oxfordjournals.pcp.a029096

Ohkama-Ohtsu, N., Radwan, S., Peterson, A., Zhao, P., Badr, A. F., Xiang, C., et al. (2007). Characterization of the extracellular gamma-glutamyl transpeptidases, GGT1 and GGT2, in Arabidopsis. Plant J. 49, 865-877. doi: 10.1111/j.1365313X.2006.03004.X

Orozco-Cardenas, M., and Ryan, C. A. (1999). Hydrogen peroxide is generated systemically in plant leaves by wounding and systemin via the octadecanoid pathway. Proc. Natl. Acad. Sci. U.S.A. 96, 6553-6557. doi: 10.1073/pnas.96.11. 6553

Otter, T., and Polle, A. (1997). Characterisation of acidic and basic apoplastic peroxidase from needles of Norway spruce (Picea abies, L., Karsten) with respect to lignifying substrates. Plant Cell Physiol. 38, 595-602. doi: 10.1093/ oxfordjournals.pcp.a029209

Paciolla, C., De Tullio, M. C., Chiappetta, A., Innocenti, A. M., Bitonti, M. B., Liso, R., et al. (2001). Short- and long-term effects of dehydroascorbate in Lupinus albus and Allium cepa roots. Plant Cell Physiol. 42, 857-863. doi: $10.1093 / \mathrm{pcp} / \mathrm{pce} 113$

Parra-Lobato, M. C., Fernandez-Garcia, N., Olmos, E., Alvarez-Tinaut, M. C., and Gómez-Jiménez, M. C. (2009). Methyl jasmonate-induced antioxidant defence in root apoplast from sunflower seedlings. Environ. Exp. Bot. 66, 9-17. doi: 10.1016/j.envexpbot.2009.01.002

Parsons, H. T., and Fry, S. C. (2012). Oxidation of dehydroascorbic acid and 2,3diketogulonate under plant apoplastic conditions. Phytochemistry 75, 41-49. doi: 10.1016/j.phytochem.2011.12.005

Pastori, G. M., Kiddle, G., Antoniw, J., Bernard, S., Veljovic-Jovanovic, S., Verrier, P. J., et al. (2003). Leaf vitamin C contents modulate plant defense transcripts and regulate genes that control development through hormone signaling. Plant Cell 15, 939-951. doi: 10.1105/tpc.010538

Pedreira, J., Herrera, M. T., Zarra, I., and Revilla, G. (2011). The overexpression of AtPrx37, an apoplastic peroxidase, reduces growth in Arabidopsis. Physiol. Plant. 141, 177-187. doi: 10.1111/j.1399-3054.2010.01427.x

Pedreira, J., Sanz, N., Peña, M. J., Sánchez, M., Queijeiro, E., Revilla, G., et al. (2004). Role of apoplastic ascorbate and hydrogen peroxide in the control of cell growth in pine hypocotyls. Plant Cell Physiol. 45, 530-534. doi: 10.1093/pcp/ pch059

Pignocchi, C., and Foyer, C. H. (2003). Apoplastic ascorbate metabolism and its role in the regulation of cell signalling. Curr. Opin. Plant Biol. 6, 379-389. doi: 10.1016/S1369-5266(03)00069-4

Planas-Portell, J., Gallart, M., Tiburcio, A. F., and Altabella, T. (2013). Coppercontaining amine oxidases contribute to terminal polyamine oxidation in 
peroxisomes and apoplast of Arabidopsis thaliana. BMC Plant Biol. 13:109. doi: 10.1186/1471-2229-13-109

Podgórska, A., Ostaszewska, M., Gardeström, P., Rasmusson, A. G., and Szal, B. (2015). In comparison with nitrate nutrition, ammonium nutrition increases growth of the frostbite1 Arabidopsis mutant. Plant Cell Environ. 38, 224-237. doi: $10.1111 /$ pce. 12404

Potters, G., Horemans, N., Bellone, S., Caubergs, R. J., Trost, P., Guisez, Y., et al. (2004). Dehydroascorbate influences the plant cell cycle through a glutathione-independent reduction mechanism. Plant Physiol. 134, 1479-1487. doi: $10.1104 /$ pp.103.033548

Potters, G., Horemans, N., Caubergs, R. J., and Asard, H. (2000). Ascorbate and dehydroascorbate influence cell cycle progression in a tobacco cell suspension. Plant Physiol. 124, 17-20. doi: 10.1104/pp.124.1.17

Pourrut, B., Perchet, G., Silvestre, J., Cecchi, M., Guiresse, M., and Pinelli, E. (2007). Potential role of NADPH-oxidase in early steps of lead-induced oxidative burst in Vicia faba roots. J. Plant Physiol. 165, 571-579. doi: 10.1016/j.jplph.2007. 07.016

Raggi, S., Ferrarini, A., Delledonne, M., Dunand, C., Ranocha, P., De Lorenzo, G., et al. (2015). The Arabidopsis thaliana class III Peroxidase AtPRX71 negatively regulates growth under physiological conditions and in response to cell wall damage. Plant Physiol. 169, 2513-2525. doi: 10.1104/pp.15.01464

Ranieri, A., Castagna, A., Pacini, J., Baldan, B., Mensuali Sodi, A., and Soldatini, G. F. (2003). Early production and scavenging of hydrogen peroxide in the apoplast of sunflower plants exposed to ozone. J. Exp. Bot. 54, 2529-2540. doi: $10.1093 /$ jxb/erg270

Rao, M. V., Lee, H. I., and Davis, K. R. (2002). Ozone-induced ethylene production is dependent on salicylic acid, and both salicylic acid and ethylene act in concert to regulate ozone-induced cell death. Plant J. 32, 447-456. doi: 10.1046/j.1365313X.2002.01434.x

Rea, G., de Pinto, M. C., Tavazza, R., Biondi, S., Gobbi, V., Ferrante, P., et al. (2004). Ectopic expression of maize polyamine oxidase and pea copper amine oxidase in the cell wall of tobacco plants. Plant Physiol. 134, 1414-1426. doi: 10.1104/pp.103.036764

Reichheld, J. P., Vernoux, T., Lardon, F., Van Montagu, M., and Inzé, D. (1999). Specific checkpoints regulate plant cell cycle progression in response to oxidative stress. Plant J. 17, 647-656. doi: 10.1046/j.1365-313X.1999. 00413.x

Remans, T., Opdenakker, K., Guisez, Y., Carleer, R., Schat, H., Vangronsveld, J., et al. (2012). Exposure of Arabidopsis thaliana to excess $\mathrm{Zn}$ reveals a $\mathrm{Zn}$ specific oxidative stress signature. Environ. Exp. Bot. 84, 61-71. doi: 10.1016/ j.envexpbot.2012.05.005

Remans, T., Opdenakker, K., Smeets, K., Mathijsen, D., Vangronsveld, J., and Cuypers, A. (2010). Metal-specific and NADPH oxidase dependent changes in lipoxygenase and NADPH oxidase gene expression in Arabidopsis thaliana exposed to cadmium or excess copper. Funct. Plant Biol. 37, 532-544. doi: 10.1071/FP09194

Rodríguez-Celma, J., Ceballos-Laita, L., Grusak, M. A., Abadía, J., and LópezMillán, A. F. (2016). Plant fluid proteomics: delving into the xylem sap, phloem sap and apoplastic fluid proteomes. Biochim. Biophys. Acta 1864, 991-1002. doi: 10.1016/j.bbapap.2016.03.014

Rosenfeld, N., Elowitz, M. B., and Alon, U. (2002). Negative autoregulation speeds the response times of transcription networks. J. Mol. Biol. 323, 785-793. doi: 10.1016/S0022-2836(02)00994-4

Sagi, M., and Fluhr, R. (2001). Superoxide production by plant homologues of the gp91(phox) NADPH oxidase. Modulation of activity by calcium and by tobacco mosaic virus infection. Plant Physiol. 126, 1281-1290. doi: 10.1104/pp.126.3. 1281

Sagi, M., and Fluhr, R. (2006). Production of reactive oxygen species by plant NADPH oxidases. Plant Physiol. 141, 336-340. doi: 10.1104/pp.106. 078089

Saidi, Y., Finka, A., Muriset, M., Bromberg, Z., Weiss, Y. G., Maathuis, F. J., et al. (2009). The heat shock response in moss plants is regulated by specific calciumpermeable channels in the plasma membrane. Plant Cell 21, 2829-2843. doi: $10.1105 /$ tpc.108.065318

Saidi, Y., Peter, P., Finka, A., Cicekli, C., Vigh, L., and Goloubinoff, P. (2010). Membrane lipid composition affects plant heat sensing and modulates $\mathrm{Ca}^{2+}$ dependent heat shock response. Plant Signal. Behav. 5, 1530-1533. doi: 10.4161/ psb.5.12.13163
Salguero, J., and Böttger, M. (1995). Secreted catalase activity from roots of developing maize (Zea mays L.) seedlings. Protoplasma 184, 72-78. doi: 10.1007/BF01276903

Sánchez-Fernández, R., Fricker, M., Corben, L. B., White, N. S., Sheard, N., Leaver, C. J., et al. (1997). Cell proliferation and hair tip growth in the Arabidopsis root are under mechanistically different forms of redox control. Proc. Natl. Acad. Sci. U.S.A. 94, 2745-2750. doi: 10.1073/pnas.94.6.2745

Santner, A., and Estelle, M. (2009). Recent advances and emerging trends in plant hormone signalling. Nature 459, 1071-1078. doi: 10.1038/nature08122

Sauter, A., and Hartung, W. (2000). Radial transport of abscisic acid conjugates in maize roots: its implication for long distance stress signals. J. Exp. Bot. 51, 929-935. doi: 10.1093/jxb/51.346.929

Schmidt, R., Kunkowska, A. B., and Schippers, J. H. M. (2016). Role of reactive oxygen species during cell expansion in leaves. Plant Physiol. 172, 2098-2106. doi: $10.1104 /$ pp.16.00426

Schopfer, P., Liszkay, A., Bechtold, M., Frahry, G., and Wagner, A. (2002). Evidence that hydroxyl radicals mediate auxin-induced extension growth. Planta 214, 821-828. doi: 10.1007/s00425-001-0699-8

Shapiguzov, A., Vainonen, J. P., Wrzaczek, M., and Kangasjärvi, J. (2012). ROStalk - how the apoplast, the chloroplast, and the nucleus get the message through. Front. Plant Sci. 3:292. doi: 10.3389/fpls.2012.00292

Shigeto, J., Itoh, Y., Hirao, S., Ohira, K., Fujita, K., and Tsutsumi, Y. (2015). Simultaneously disrupting AtPrx2, AtPrx25 and AtPrx71 alters lignin content and structure in Arabidopsis stem. J. Integr. Plant. Biol. 57, 349-356. doi: $10.1111 /$ jipb. 12334

Shigeto, J., Kiyonaga, Y., Fujita, K., Kondo, R., and Tsutsumi, Y. (2013). Putative cationic cell-wall-bound peroxidase homologues in Arabidopsis, AtPrx2, AtPrx25, and AtPrx71, are involved in lignification. J. Agric. Food Chem. 61, 3781-3788. doi: 10.1021/jf400426g

Shigeto, J., and Tsutsumi, Y. (2016). Diverse functions and reactions of class III peroxidases. New Phytol. 209, 1395-1402. doi: 10.1111/nph.13738

Sierla, M., Rahikainen, M., Salojärvi, J., Kangasjärvi, J., and Kangasjärvi, S. (2013). Apoplastic and chloroplastic redox signaling networks in plant stress responses. Antioxid. Redox. Signal. 18, 2220-2239. doi: 10.1089/ars.2012.5016

Simon, H. U., Haj-Yehia, A., and Levi-Schaffer, F. (2000). Role of reactive oxygen species (ROS) in apoptosis induction. Apoptosis 5, 415-418. doi: 10.1023/a: 1009616228304

Singh, K., Foley, R. C., and Oñate-Sánchez, L. (2002). Transcription factors in plant defense and stress responses. Curr. Opin. Plant Biol. 5, 430-436. doi: 10.1016/S1369-5266(02)00289-3

Smirnoff, N. (1996). The function and metabolism of ascorbic acid in plants. Ann. Bot. 78, 661-669. doi: 10.1006/anbo.1996.0175

Sobahan, M. A., Arias, C. R., Okuma, E., Shimoishi, Y., Nakamura, Y., Hirai, Y., et al. (2009). Exogenous proline and glycinebetaine suppress apoplastic flow to reduce $\mathrm{Na}+$ uptake in rice seedlings. Biosci. Biotechnol. Biochem. 73, 2037-2042. doi: $10.1271 /$ bbb. 90244

Sobieszczuk-Nowicka, E., Kubala, S., Zmienko, A., Małecka, A., and Legocka, J. (2016). From accumulation to degradation: reprogramming polyamine metabolism facilitates dark-induced senescence in barley leaf cells. Front. Plant Sci. 6:1198. doi: 10.3389/fpls.2015.01198

Song, C. J., Steinebrunner, I., Wang, X., Stout, S. C., and Roux, S. J. (2006). Extracellular ATP induces the accumulation of superoxide via NADPH oxidases in Arabidopsis. Plant Physiol. 140, 1222-1232. doi: 10.1104/pp.105. 073072

Spadaro, D., Yun, B. W., Spoel, S. H., Chu, C., Wang, Y. Q., and Loake, G. J. (2010). The redox switch: dynamic regulation of protein function by cysteine modifications. Physiol. Plant. 138, 360-371. doi: 10.1111/j.1399-3054.2009. 01307.x

Stanley Kim, H., Yu, Y., Snesrud, E. C., Moy, L. P., Linford, L. D., Haas, B. J., et al. (2005). Transcriptional divergence of the duplicated oxidative stress-responsive genes in the Arabidopsis genome. Plant J. 41, 212-220. doi: 10.1111/j.1365313X.2004.02295.x

Steinhorst, L., and Kudla, J. (2013). Calcium and reactive oxygen species rule the waves of signaling. Plant Physiol. 163, 471-485. doi: 10.1104/pp.113.222950

Storozhenko, S., Belles-Boix, E., Babiychuk, E., Hérouart, D., Davey, M. W., Slooten, L., et al. (2002). Gamma-glutamyl transpeptidase in transgenic tobacco plants. Cellular localization, processing, and biochemical properties. Plant Physiol. 128, 1109-1119. doi: 10.1104/pp.010887 
Sumimoto, H. (2008). Structure, regulation and evolution of Nox-family NADPH oxidases that produce reactive oxygen species. FEBS J. 275, 3249-3277. doi: 10.1111/j.1742-4658.2008.06488.x

Sun, A. Z., and Guo, F. Q. (2016). Chloroplast retrograde regulation of heat stress responses in plants. Front. Plant Sci. 7:398. doi: 10.3389/fpls.2016.00398

Survila, M., Davidsson, P. R., Pennanen, V., Kariola, T., Broberg, M., Sipari, N., et al. (2016). Peroxidase-generated apoplastic ROS impair cuticle integrity and contribute to DAMP-elicited defenses. Front. Plant Sci. 7:1945. doi: 10.3389/ fpls.2016.01945

Suzuki, N., Koussevitzky, S., Mittler, R., and Miller, G. (2012). ROS and redox signalling in the response of plants to abiotic stress. Plant Cell Environ. 35, 259-270. doi: 10.1111/j.1365-3040.2011.02336.x

Takahama, U., and Oniki, T. (1992). Regulation of peroxidase-dependent oxidation of phenolics in the apoplast of spinach leaves by ascorbate. Plant Cell Physiol. 33, 379-387.

Takeda, S., Gapper, C., Kaya, H., Bell, E., Kuchitsu, K., and Dolan, L. (2008). Local positive feedback regulation determines cell shape in root hair cells. Science 319, 1241-1244. doi: 10.1126/science. 1152505

Taubert, D., Breitenbach, T., Lazar, A., Censarek, P., Harlfinger, S., Berkels, R., et al. (2003). Reaction rate constants of superoxide scavenging by plant antioxidants. Free Radic. Biol. Med. 35, 1599-1607. doi: 10.1016/j.freeradbiomed.2003. 09.005

Tavladoraki, P., Cona, A., and Angelini, R. (2016). Copper-containing amine oxidases and FAD-dependent polyamine oxidases are key players in plant tissue differentiation and organ development. Front. Plant Sci 7:824. doi: 10.3389/fpls. 2016.00824

Tavladoraki, P., Rossi, M. N., Saccuti, G., Perez-Amador, M. A., Polticelli, F., Angelini, R., et al. (2006). Heterologous expression and biochemical characterization of a polyamine oxidase from Arabidopsis involved in polyamine back conversion. Plant Physiol. 141, 1519-1532. doi: 10.1104/pp.106. 080911

Tejera, N., Ortega, E., Rodes, R., and Lluch, C. (2006). Nitrogen compounds in the apoplastic sap of sugarcane stem: some implications in the association with endophytes. J. Plant Physiol. 163, 80-85. doi: 10.1016/j.jplph.2005. 03.010

Tognolli, M., Penel, C., Greppin, H., and Simon, P. (2002). Analysis and expression of the class III peroxidase large gene family in Arabidopsis thaliana. Gene 288, 129-138. doi: 10.1016/s0378-1119(02)00465-1

Tron, A. E., Bertoncini, C. W., Chan, R. L., and Gonzalez, D. H. (2002). Redox regulation of plant homeodomain transcription factors. J. Biol. Chem. 277, 34800-34807. doi: 10.1074/jbc.M203297200

Valério, L., De Meyer, M., Penel, C., and Dunand, C. (2004). Expression analysis of the Arabidopsis peroxidase multigenic family. Phytochemistry 65, 1331-1342. doi: 10.1016/j.phytochem.2004.04.017

Van Breusegem, F., Bailey-Serres, J., and Mittler, R. (2008). Unraveling the tapestry of networks involving reactive oxygen species in plants. Plant Physiol. 147, 978-984. doi: 10.1104/pp.108.122325

Van Huystee, R. B., Roig, M. G., Shnyrov, V. L., and Sakharov, I. Y. (2004). Peroxidase stability related to its calcium and glycans. Phytochem. Rev. 3, 19-28. doi: 10.1023/B:PHYT.0000047802.79211.32

Vanacker, H., Carver, T. L., and Foyer, C. H. (1998a). Pathogen-induced changes in the antioxidant status of the apoplast in barley leaves. Plant Physiol. 117, 1103-1114.

Vanacker, H., Harbinson, J., Ruisch, J., Carver, T. L. W., and Foyer, C. H. (1998b). Antioxidant defences of the apoplast. Protoplasma 205, 129-140. doi: 10.1007/ BF01279303

Wallace, G., and Fry, S. C. (1994). Phenolic compounds of the plant cell wall. Int. Rev. Cytol. 151, 229-267. doi: 10.1016/S0074-7696(08)62634-0

Wan, X. Y., and Liu, J. Y. (2008). Comparative proteomics analysis reveals an intimate protein network provoked by hydrogen peroxide stress in rice seedling leaves. Mol. Cell. Proteomics 7, 1469-1488. doi: 10.1074/mcp. M700488-MCP200
Watanabe, T., Seo, S., and Sakai, S. (2001). Wound-induced expression of a gene for 1-aminocyclopropan1-1-carboxylate synthase and ethylene production are regulated by both reactive oxygen species and jasmonic acid in Cucurbita maxima. Plant Physiol. Biochem. 39, 121-127. doi: 10.1016/S0981-9428(00) 01224-9

Wilkinson, S., and Davies, W. J. (2002). ABA-based chemical signalling: the coordination of responses to stress in plants. Plant Cell Environ. 25, 195-210. doi: 10.1046/j.0016-8025.2001.00824.x

Wimalasekera, R., Villar, C., Begum, T., and Scherer, G. F. (2011). Copper Amine Oxidase1 (CuAO1) of Arabidopsis thaliana contributes to abscisic acid-and polyamine-induced nitric oxide biosynthesis and abscisic acid signal transduction. Mol. Plant 4, 663-678. doi: 10.1093/mp/ssr023

Wong, H. L., Pinontoan, R., Hayashi, K., Tabata, R., Yaeno, T., Hasegawa, K., et al. (2007). Regulation of rice NADPH oxidase by binding of Rac GTPase to its N-Terminal extension. Plant Cell 19, 4022-4034. doi: 10.1105/tpc.107. 055624

Xia, X. J., Zhou, Y. H., Shi, K., Zhou, J., Foyer, C. H., and Yu, J. Q. (2015). Interplay between reactive oxygen species and hormones in the control of plant development and stress tolerance. J. Exp. Bot. 66, 2839-2856. doi: 10.1093/jxb/ erv089

Zechmann, B., Mauch, F., Sticher, L., and Müller, M. (2008). Subcellular immunocytochemical analysis detects the highest concentrations of glutathione in mitochondria and not in plastids. J. Exp. Bot. 59, 4017-4027. doi: 10.1093/ jxb/ern 243

Zhang, F., Zhang, H., Wang, G., Xu, L., and Shen, Z. (2009). Cadmium-induced accumulation of hydrogen peroxide in the leaf apoplast of Phaseolus aureus and Vicia sativa and the roles of different antioxidant enzymes. J. Hazard. Mater. 168, 76-84. doi: 10.1016/j.jhazmat.2009.02.002

Zhang, M. Y., Bourbouloux, A., Cagnac, O., Srikanth, C. V., Rentsch, D., Bachhawat, A. K., et al. (2004). A novel family of transporters mediating the transport of glutathione derivatives in plants. Plant Physiol. 134, 482-491. doi: 10.1104/pp.103.030940

Zhang, Y., Zhu, H., Zhang, Q., Li, M., Yan, M., Wang, R., et al. (2009). Phospholipase $\mathrm{D} \alpha 1$ and phosphatidic acid regulate NADPH oxidase activity and production of reactive oxygen species in ABA-mediated stomatal closure in Arabidopsis. Plant Cell 21, 2357-2377. doi: 10.1105/tpc.108. 062992

Zhao, J. (2016). Flavonoid transport mechanisms: how to go, and with whom. Trends Plant Sci. 20, 576-585. doi: 10.1016/j.tplants.2015. 06.007

Zhou, J., Wang, J., Shi, K., Xia, X. J., Zhou, Y. H., and Yu, J. Q. (2012). Hydrogen peroxide is involved in the cold acclimation-induced chilling tolerance of tomato plants. Plant Physiol. Biochem. 60, 141-149. doi: 10.1016/j.plaphy.2012. 07.010

Zhou, L., Bokhari, S. A., Dong, C. J., and Liu, J. Y. (2011). Comparative proteomics analysis of the root apoplasts of rice seedlings in response to hydrogen peroxide. PLoS ONE 6:e16723. doi: 10.1371/journal.pone.0016723

Źróbek-Sokolnik, A., Asard, H., Górska-Koplińska, K., and Górecki, R. J. (2009). Cadmium and zinc-mediated oxidative burst in tobacco BY-2 cell suspension cultures. Acta Physiol. Plant. 31, 43-49. doi: 10.1007/s11738-0080197-8

Conflict of Interest Statement: The authors declare that the research was conducted in the absence of any commercial or financial relationships that could be construed as a potential conflict of interest.

Copyright (c) 2017 Podgórska, Burian and Szal. This is an open-access article distributed under the terms of the Creative Commons Attribution License (CC BY). The use, distribution or reproduction in other forums is permitted, provided the original author(s) or licensor are credited and that the original publication in this journal is cited, in accordance with accepted academic practice. No use, distribution or reproduction is permitted which does not comply with these terms. 